ФЕДЕРАЛЬНЫЙ ИССЛЕДОВАТЕЛЬСКИЙ ЦЕНТР КОЛЬСКИЙ НАУЧНЫЙ ЦЕНТР

РОССЙЙКОЙ АКАДЕМИИ НАУК ГОРНЫЙ ИНСТИТУТ

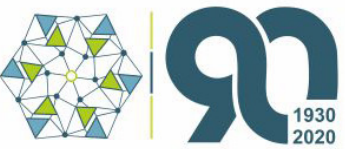

ФЕДЕРАЛЬНОГО ИССЛЕДОВАТЕЛЬСКОГО ЦЕНТРА

"КОЛЬСКИЙ НАУЧНЫЙ ЦЕНТР РОССИЙСКОЙ АКАДЕМИИ НАУК»

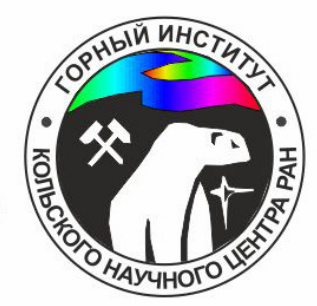

\title{
МЕТОДИКА ВИЗУАЛЬНЬХ
} НАБЛЮДЕНИЙ В ПОДЗЕМНЫХ ГОРНЫХ ВЫРАБОТКАХ

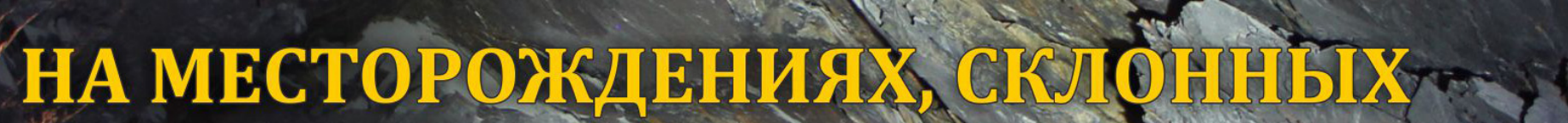
И ОПАСНЫХ ПО ГОРНЫЫМ УДАРАМ

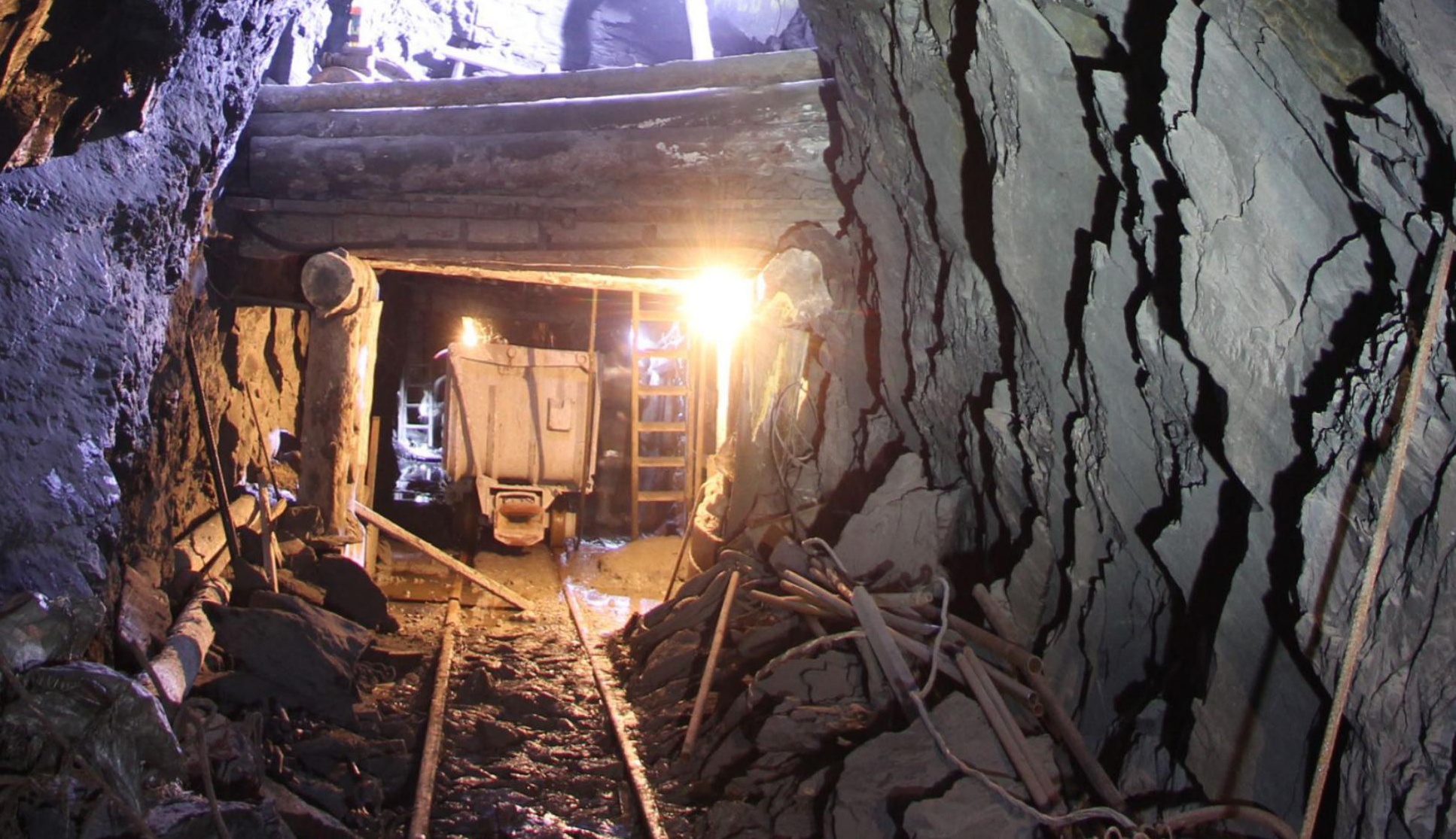


МИНИСТЕРСТВО НАУКИ И ВЫСШЕГО ОБРАЗОВАНИЯ РОССИЙСКОЙ ФЕДЕРАЦИИ ФЕДЕРАЛЬНЫЙ ИССЛЕДОВАТЕЛЬСКИЙ ЦЕНТР «КОЛЬСКИЙ НАУЧНЫЙ ЦЕНТР РОССИЙСКОЙ АКАДЕМИИ НАУК» гОРнЫЙ ИнСТиТУТ

А. В. Пантелеев, Э. В. Каспарьян, И. Э. Семенова

\title{
МЕТОДИКА ВИЗУАЛЬНЫХ НАБЛЮДЕНИЙ В ПОДЗЕМНЫХ ГОРНЫХ ВЫРАБОТКАХ НА МЕСТОРОЖДЕНИЯХ, СКЛОННЫХ И ОПАСНЫХ ПО ГОРНЫМ УДАРАМ
}

\author{
Под редакцией профессора, \\ доктора технических наук А. А. Козырева
}

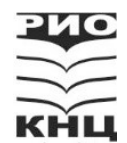

Издательство Кольского научного центра 2020 
DOI: $10.37614 / 978.5 .91137 .436 .5$

УДК 622.831

ББК 33

$\Pi 16$

Печатается по решению редакционно-издательского совета Федерального исследовательского центра «Кольский научный центр Российской академии наук»

Рецензенты:

доктор технических наук В. А. Еременко, доктор технических наук В. В. Рыбин

Пантелеев, А. В.
П16 Методика визуальных наблюдений в подземных горных выработках на месторождениях, склонных и опасных по горным ударам / А. В. Пантелеев, Э. В. Каспарьян, И. Э. Семенова; под ред. А. А. Козырева. - Апатиты: Издательство ФИЦ КНЦ РАН, 2020. - 68 с.: ил. + Прил.

ISBN 978-5-91137-436-5

Рассмотрен один из основных методов оценки состояния горных выработок при разработке запасов месторождений, склонных и опасных по горным ударам. Обоснован научный подход при проведении визуального обследования горных выработок, позволяющий получить приближенные характеристики типа и параметров поля напряжений отдельных участков месторождения и разработать адекватные мероприятия по обеспечению их устойчивости.

Представлены результаты исследований приконтурного массива горных выработок, полученные сотрудниками Горного института ФИЦ КНЦ РАН на подземных рудниках Кольского полуострова в течение нескольких десятилетий.

Издание предназначено для специалистов, ведущих работы в подземных условиях, а также для инженерных и научных работников, осуществляющих геомеханическое сопровождение горных работ.

Издание подготовлено в рамках государственного задания по теме НИР 0226-2019-0058.

\section{Препринт}

Технический редактор В. Ю. Жиганов

Подписано в печать 03.09.2020. Формат бумаги 60×84 1/16. Усл. печ. л. 5.95. Заказ № 50. Тираж 500 экз.

ISBN 978-5-91137-436-5

(c) А. В. Пантелеев, Э. В. Каспарьян, И. Э. Семенова, 2020

(C Горный институт ФГБУН ФИЦ КНЦ РАН, 2020

(C) ФГБУН ФИЦ «Кольский научный центр Российской академии наук», 2020 


\section{ОГЛАВЛЕНИЕ}

ПРЕДИСЛОВИЕ ........................................................................ 4

ВВЕДЕНИЕ ............................................................................. 5

1. ОСНОВНЫЕ ЗАКОНОМЕРНОСТИ РАСПРЕДЕЛЕНИЯ НАПРЯЖЕНИЙ

В ПРИКОНТУРНОЙ ЧАСТИ МАССИВА, ОПРЕДЕЛЯЮЩИЕ ХАРАКТЕР

РАЗРУШЕНИЯ КОНТУРА ВЫРАБОТОК

7

2. ОСОБЕННОСТИ ПРОЯВЛЕНИЯ ПОВЫШЕННОГО ГОРНОГО

ДАВЛЕНИЯ НА КОНТУРЕ ГОРНЫХ ВЫРАБОТОК

9

3. ОРГАНИЗАЦИЯ И ВЫПОЛНЕНИЕ ВИЗУАЛЬНЫХ

НАБЛЮДЕНИЙ ............................................................................ 28

3.1. Цели и задачи, периодичность выполнения работ ........................ 28

3.2. Техника безопасности ................................................................ 29

3.3. Оборудование ....................................................................... 31

3.4. Порядок выполнения работ и первичная документация ............... 34

3.5. Камеральная обработка ……................................................... 42

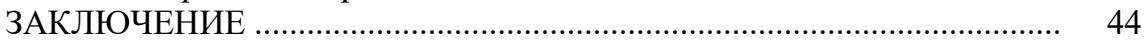

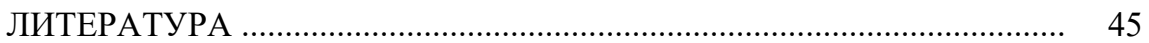

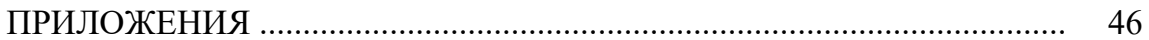




\section{ПРЕДИСЛОВИЕ}

Рассмотрены аспекты проведения и анализа результатов визуальных наблюдений в подземных горных выработках на месторождениях, склонных и опасных по горным ударам. Основной целью подобных исследований является выявление участков выработок с внешними признаками удароопасности для разработки мероприятий по обеспечению их устойчивости. Материалы подготовлены на основе опыта, полученного при визуальном обследовании выработок на подземных рудниках Кольского полуострова в течение нескольких десятилетий. $\mathrm{B}$ работе учтены требования действующих нормативных документов.

Методика может представлять интерес для работников, руководителей и специалистов, ведущих работы в подземных горных выработках, а также для научных работников, осуществляющих геомеханическое сопровождение горных работ. Она будет полезна сотрудникам служб прогноза и предупреждения горных ударов подземных горнорудных предприятий.

Материалы дополнены: перечнем специальных терминов и сокращений, используемых в тексте (приложение 1); каталогом идентификаторов категории состояния выработок (приложение 2); перечнем условных обозначений (приложение 3).

Ссылки на нормативные документы обозначены в тексте их кратким названием и номером в списке литературы (например: Положение... [7]), а на литературные источники только порядковым номером в квадратных скобках (например: [1]).

Издание подготовлено под общим руководством и научной редакцией профессора, доктора технических наук А. А. Козырева. 


\section{ВВЕДЕНИЕ}

Закономерной тенденцией развития горных работ является увеличение доли добычи полезных ископаемых подземным способом, а также их интенсификация и возрастание глубины отработки.

Ежегодно на подземных рудниках проходятся километры выработок, сотни километров одновременно находятся в эксплуатации. Их поддержание и безопасная эксплуатация требуют значительных материальных затрат.

Устойчивость выработок определяется, главным образом, состоянием приконтурной области, на которую оказывают влияние как природные условия (свойства слагающих массив пород, структурные неоднородности, естественное поле напряжений, водонасыщенность и т. п.), так и техногенные, связанные с особенностями применяемой системы отработки, расположением выработок, их размерами, формой сечения и т. П. Оценка состояния приконтурной части массива является важнейшей задачей инженерных служб, эксплуатирующих месторождение и обеспечивающих безопасность ведения горных работ.

Существует ряд инструментальных методов изучения данного состояния, в основе которых лежат фиксация разрушения породы, измерения деформаций или контроль изменения их физических характеристик $[1,2]$. Для прогноза напряженно-деформированного состояния (НДС) массива и выработок по мере развития горных работ используются также численные методы [3].

К положительным чертам инструментальных методов можно отнести их относительную объективность. Негативная сторона заключается в значительных материальных и временных затратах, необходимости выполнения работ в опасных условиях в течение длительного времени, а также в ограниченности распространения полученных локальными методами результатов на другие участки массива.

Методом, не использующим сложного инструментария при прогнозе удароопасности, а также при оценке эффективности принятых мер по предупреждению горных ударов, является визуальное наблюдение за состоянием приконтурной части выработок.

Как правило, перед постановкой инструментальных измерений выполняется визуальное обследование, на основе которого устанавливается предварительная схема развивающихся процессов, намечаются места проведения детальных исследований. Как показывает опыт, во многих случаях при соответствующем качестве выполнения визуальных наблюдений можно уже на этом этапе получить необходимую, достаточно полную информацию и сформулировать обоснованные выводы о состоянии выработок. Важным преимуществом визуального метода является то, что он, не требуя сложного оборудования, 
позволяет в короткие сроки провести оценку состояния массива в больших объемах, в пределах которых имеются горные выработки.

Визуальные наблюдения являются неотъемлемой частью любых геомеханических исследований. Это самостоятельный вид работ, который в условиях удароопасных месторождений регулярно выполняется работниками служб прогноза и предупреждения горных ударов (СППГУ). Довольно часто визуальное обследование является единственным возможным способом получения информации, особенно когда требуется оценить состояние выработки в предельно сжатые сроки в условиях повышенной опасности. Основным недостатком визуальной оценки принято считать субъективность при классификации вида и степени интенсивности проявления геомеханических процессов. Достоверность, объём и полнота получаемой информации при применении визуального метода в значительной степени определяются опытом, квалификацией и добросовестностью исполнителей.

Необходимо отметить, что, несмотря на большое значение и весьма широкое применение данного метода в геомеханике, к настоящему времени практически отсутствуют какие-либо методические разработки, регламентирующие проведение визуального обследования горных выработок в каких-либо типовых условиях или для выполнения отдельных классов геомеханических задач. В данном издании осуществлена попытка в какой-то мере восполнить этот пробел для весьма сложных условий ведения горных работ на удароопасных месторождениях. 


\section{1. ОСНОВНЫЕ ЗАКОНОМЕРНОСТИ РАСПРЕДЕЛЕНИЯ НАПРЯЖЕНИЙ В ПРИКОНТУРНОЙ ЧАСТИ МАССИВА, ОПРЕДЕЛЯЮЩИЕ ХАРАКТЕР РАЗРУШЕНИЯ КОНТУРА ВЫРАБОТОК}

Современные представления о характере и сути процессов, происходящих в массиве горных пород при проведении выработок, заключаются в выделении трех зон, в пределах которых породы находятся в качественно различном напряжённо-деформированном состоянии.

Первую зону, непосредственно примыкающую к контуру выработки, составляют, как правило, деформированные, ослабленные породы, не способные накапливать в себе повышенные напряжения, а величины действующих напряжений здесь существенно меньше, чем в нетронутом массиве. Эту зону обычно называют зоной неупругих деформаций и разрушений. Ее параметры определяются совокупным действием естественных и технологических факторов.

Параметры этой зоны, в первую очередь, определяют внешний вид, степень устойчивости контура выработки и способ ее поддержания. Как показывает многолетний опыт эксплуатации выработок в условиях скальных массивов, радиальная протяжённость зоны неупругих деформаций от контура в массив не превышает 0,4 м, при этом выработка достаточно устойчива, может эксплуатироваться без крепления.

При высокой степени напряжённости массива (в частности, в условиях удароопасных месторождений) радиальная протяжённость зоны неупругих деформаций существенно меньше, очень часто практически нулевая, и тогда непосредственно на контуре выработки обнажается вторая зона.

Вторая зона - это область, где напряжения существенно выше, чем в массиве до проведения выработки. На ее состояние оказывают влияние характер исходного поля напряжения, особенности геологического строения, зоны концентраций как самой выработки, так и близко расположенных соседних выработок, зоны опорного давления от границ очистного пространства, рельеф и т. п. Если эта зона непосредственно выходит на контур выработки, то характер разрушения меняется и ее контур приобретает специфические очертания.

Третьей зоной является область, где сохраняются условия исходного поля напряжений нетронутого массива. Оценка ее состояния доступна только с применением инструментальных методов.

Для данной работы наибольший интерес представляет вторая зона, формируемая в выработках, пройденных в породах, способных выдерживать 
значительные нагрузки и хрупко разрушаться при преодолении предела их прочности под воздействием внешних факторов.

Для разных типов горных пород характер разрушения приконтурной части массива под действием предельно допустимых напряжений разный. Менее хрупкие разновидности пород на начальном этапе повышения нагрузки проявляют пластические свойства, создавая видимость нормального состояния контура. Слабо связанный массив разрушается при незначительных нагрузках, не допуская концентраций, способных реализоваться в виде горного удара. Но подавляющее большинство рудных месторождений, сложенных магматическими, метаморфическими или в значительной степени сцементированными осадочными породами, имеет в своем строении участки, способные при определенных условиях разрушаться в динамической форме. Именно такие условия рассмотрены в данной книге.

В основу материалов легли наблюдения в течение нескольких десятилетий за динамикой состояния приконтурной части выработок на подземных рудниках, разрабатывающих хибинские апатит-нефелиновые месторождения. Использованы также материалы, полученные авторами при обследовании выработок других рудников Кольского полуострова. 


\section{2. ОСОБЕННОСТИ ПРОЯВЛЕНИЯ ПОВЫШЕННОГО ГОРНОГО ДАВЛЕНИЯ НА КОНТУРЕ ГОРНЫХ ВЫРАБОТОК}

Подземные горные работы в Хибинском массиве ведутся на глубине более 400 м от земной поверхности в условиях сильно расчлененного рельефа, что определяет весьма мозаичную структуру гравитационного поля. Расположенный в центральной части Кольского полуострова, в северной оконечности Балтийского щита, примыкающего к Срединно-Атлантической рифтовой зоне, проявляющей высокую сейсмическую активность, Хибинский массив испытывает восходящее движение со скоростью 2-4 мм в год [4], обусловленное тектонической составляющей общего тензора напряжений.

По данным инструментальных измерений, проведенных на горизонтах +172 и +92 м Кировского рудника, значения максимально сжимающих компонент тензора напряжений исходного поля составили соответственно $\approx 50$ и $\approx 60$ МПа. При этом горизонтальная (тектоническая) составляющая $\sigma_{\mathrm{T}}$ в несколько раз превысила вертикальную (гравитационную) составляющую $\sigma_{\text {н }}$

Породы и руды, слагающие хибинские месторождения, имеют высокие показатели прочности и упругости. Предел прочности при сжатии $\sigma_{\mathrm{c}}$ для руд

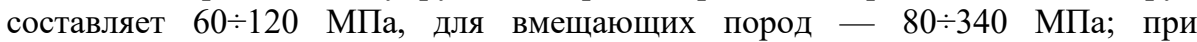
растяжении соответственно $5 \div 8$ и $8 \div 37$ МПа, коэффициент хрупкости КХР, определяемый как отношение предела прочности при сжатии к значению этого же показателя при растяжении, составляет КхР $=11 \div 19$ (Указания... $[5,6])$.

Данные свойства позволяют массиву накапливать значительную потенциальную энергию и реализовывать ее в динамической форме, вплоть до горных ударов. Как правило, нарушения контура выработок начинают проявляться при достижении максимальной сжимающей компонентой $\sigma_{\max }$ значений $0,3 \sigma_{c}$.

Рассмотрим пример разрушения контура в гравитационно-тектоническом поле напряжений, характерный для одиночных выработок, в случае существенного превышения тектонической составляющей по отношению к гравитационной $\left(\sigma_{\mathrm{T}} \gg \sigma_{\mathrm{H}}\right)$. Часть кровли и подошвы находятся в зоне максимально сжимающих напряжений (зона-I), а отдельные секторы стенок в зоне растягивающих напряжений (зона-II) (рис. 1).

Для всех выделенных зон наблюдается отслоение кусков породы, близких по конфигурации, но механизм их формирования разный. В зоне-І энергия выдавливания заколов в условиях сжатия в десятки раз превышает энергию заколообразования в зоне-II, где порода работает на растяжение. Зону-II называют также зоной отжима. Данные обстоятельства необходимо учитывать при разработке мероприятий по приведению выработок в безопасное состояние, выборе крепления и пр. 


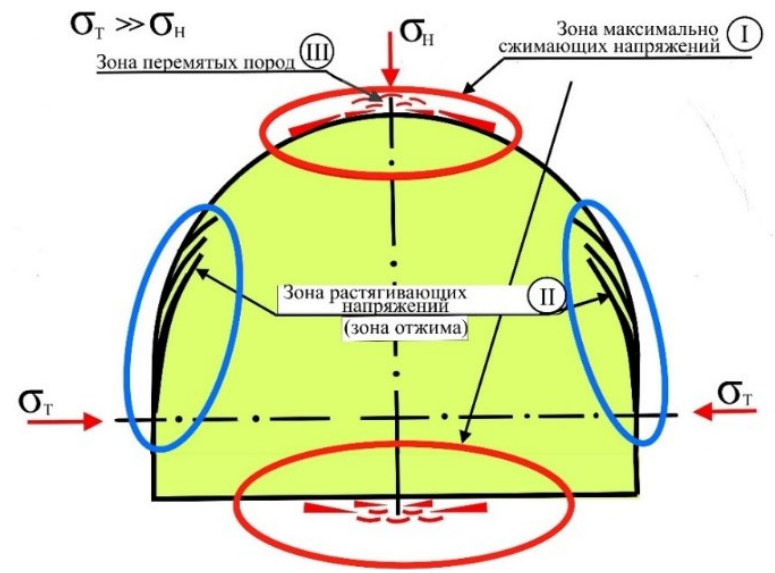

Рис. 1. Формирование зон разрушения приконтурной части выработок при $\sigma_{\mathrm{T}}>>\sigma_{\mathrm{H}}$

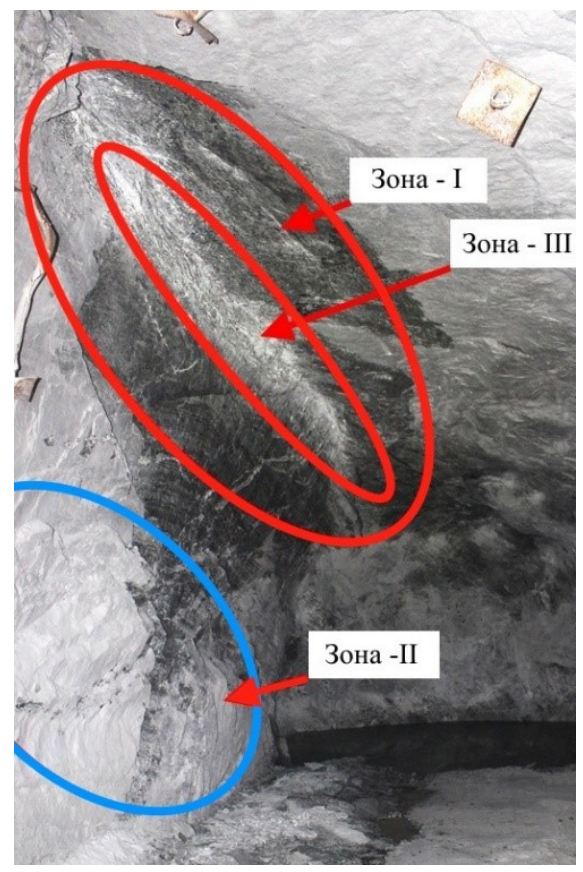

Рис. 2. Пример разрушений на контуре выработки, в зоне опорного давления от границы очистного пространства по вышележащему горизонту. Кировский рудник, горизонт +236 , отрезной штрек-32 
При значительных напряжениях в зоне-І образуются сильно перемятые породы, которые можно ошибочно принять за прожилки светлоокрашенных пород - зона-III (рис. 1, 2).

В хрупких породах средней и ниже крепости при значительных нагрузках зона-I может непосредственно переходить в зону-II (рис. 3).

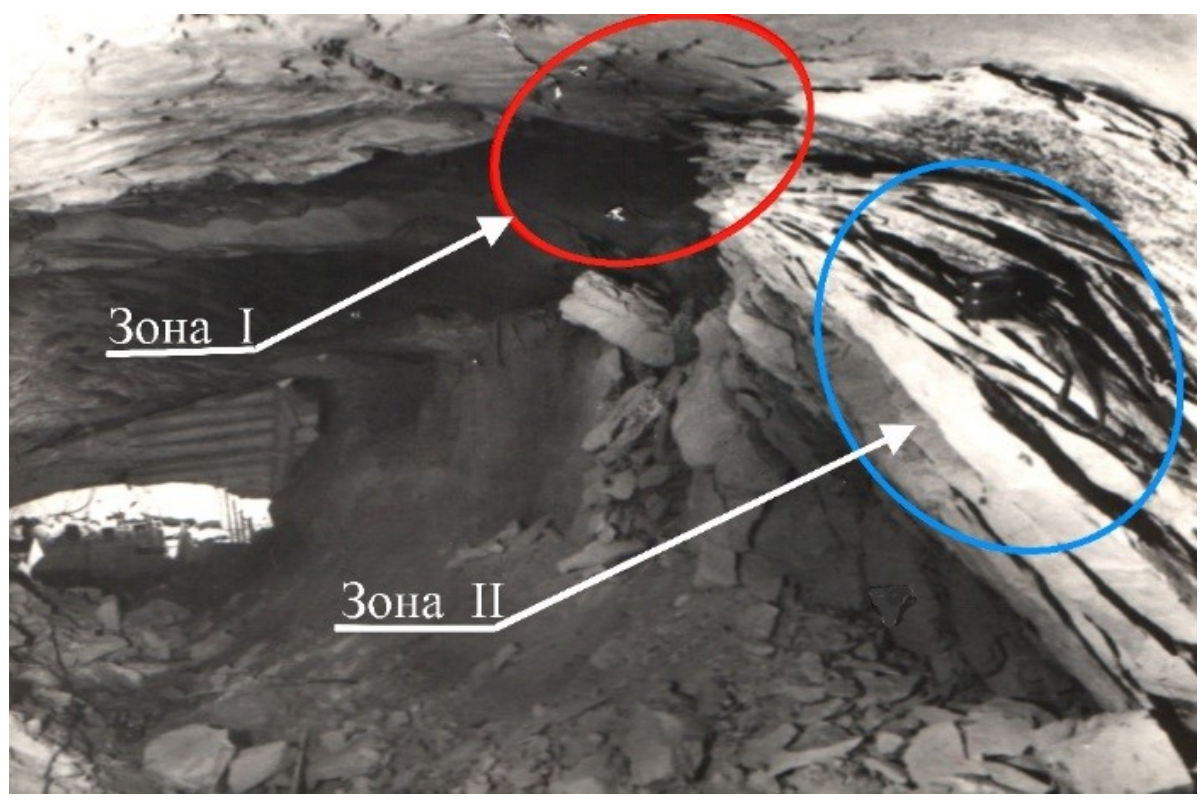

Рис. 3. Разрушение скреперного штрека, пройденного по богатой апатитнефелиновой руде. Кировский рудник, горизонт +252, скреперный штрек 1316

При различных соотношениях компонент тензора напряжений изменяется и местоположение зоны-І на контуре выработки (рис. 4). 


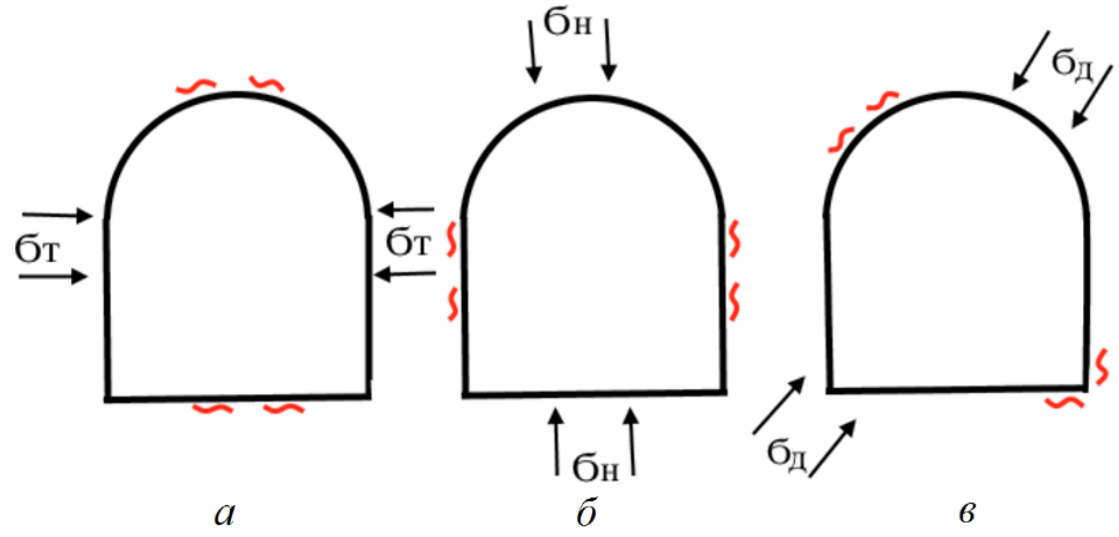

Рис. 4. Расположение зоны-I (с внешними признаками удароопасности) в зависимости от соотношения компонент тензора напряжений:

$a$ - преобладающее действие тектонической составляющей $\left(\sigma_{\mathrm{T}}>>\sigma_{\mathrm{H}}\right)$;

$\sigma$ - преобладающее действие гравитационной составляющей $\left(\sigma_{\mathrm{H}}>>\sigma_{\mathrm{T}}\right)$;

8 - действие близких по величине тектонической и гравитационной составляющих $\left(\sigma_{\mathrm{T}} \approx \sigma_{\mathrm{H}}\right)$,

где $\sigma_{\text {д }}-$ проекция компоненты главных напряжений на плоскость, перпендикулярную оси рассматриваемой выработки (действующие напряжения);

$\sim$ - внешние признаки удароопасности

При изменении соотношения действующих в массиве сжимающих напряжений к предельной прочности пород на сжатие изменяется вид и интенсивность внешних признаков удароопасности, наблюдаемых на контуре выработки. В соответствии с регламентирующими документами (Положение... [7]), к внешним признакам удароопасности (далее - внешние признаки) относятся: шелушение, интенсивное заколообразование, стреляние.

Под шелушением понимается постепенное разрушение поверхности обнажения породы на отдельные пластинки, из-за отслоения которых места шелушения всегда выглядят «свежими» - незапылёнными (рис. 5). 


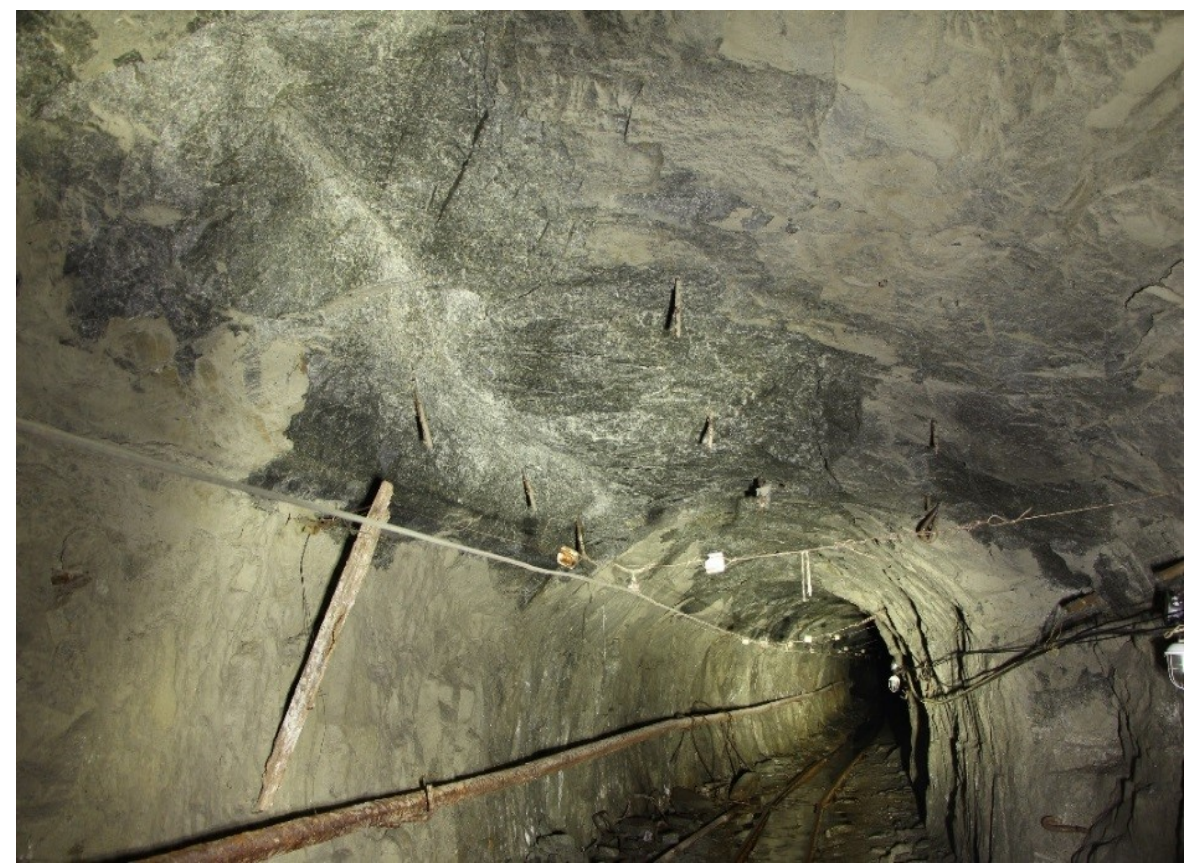

Рис. 5. Шелушение по сопряжению кровли со стенкой. Рудник «Карнасурт», западный рудный штрек

Под интенсивным заколообразованием подразумевается образование и отделение (под влиянием избыточных напряжений в массиве) заколов вслед за их оборкой в течение длительного времени, сопровождаемое треском и звуками, напоминающими выстрел. Это явление чаще всего не связано напрямую с трещиноватостью или слоистостью, образующиеся пластины повторяют по форме контур выработки.

Так как причины отделения кусков породы от массива в общем случае могут быть различными (в том числе трещиноватость, слоистость и т. п.), а скорость формирования заколов, обусловленная горным давлением, варьирует в широких пределах, на ряде предприятий для данного явления принят термин «динамическое заколообразование» (рис. 6). 


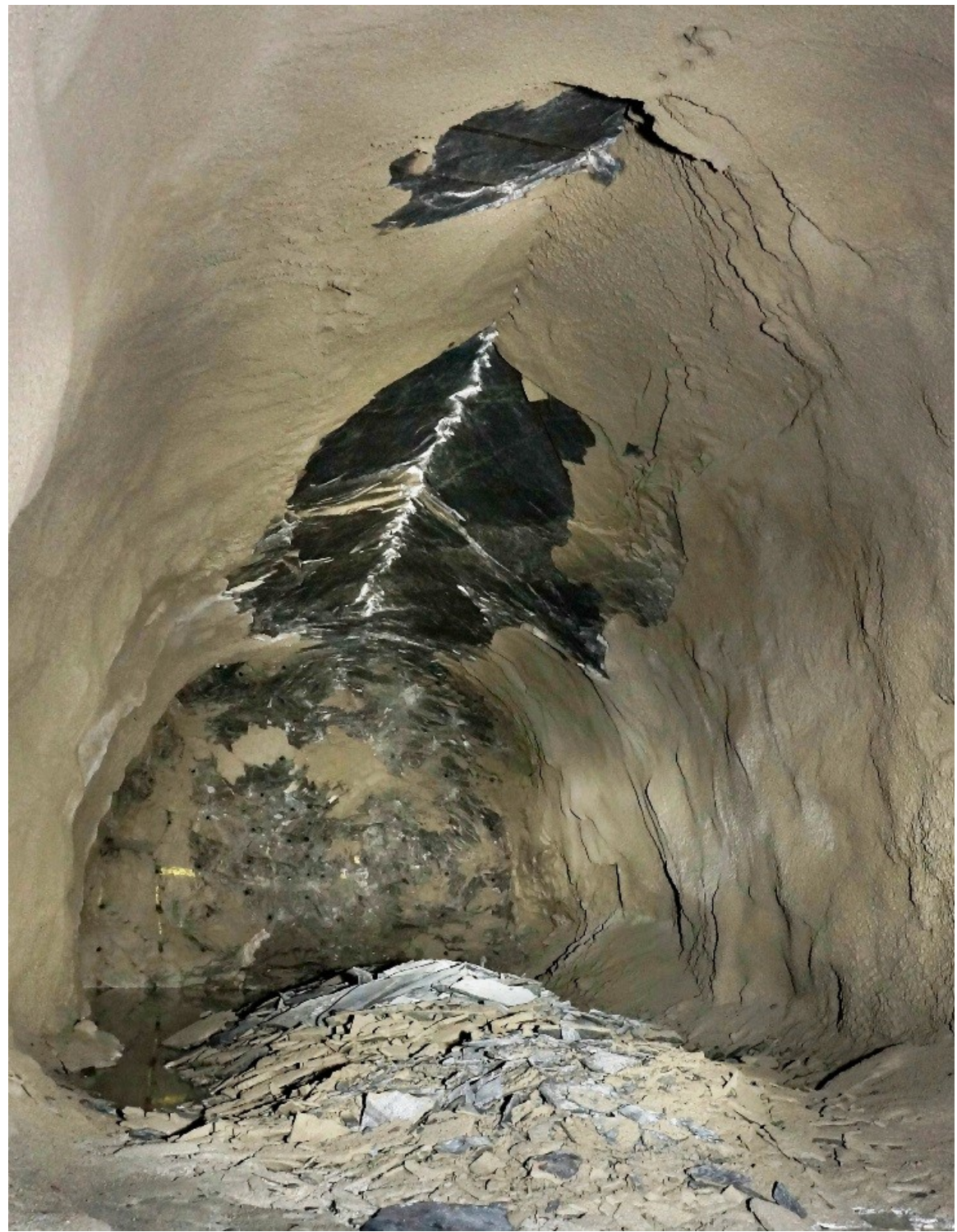

Рис. 6. Динамическое заколообразование по кровле. Расвумчоррский рудник, +310 м, квершлаг ВВС 
Стреляние подразумевает отскакивание пластин породы различных размеров с поверхности обнажения массива со звуком, напоминающим выстрел. Этот процесс наблюдается весьма редко. Чаще за стреляние принимают динамическое заколообразование и даже шелушение, которые также сопровождаются достаточно громкими и звонкими щелчками. При стрелянии прорастание трещины отрыва происходит за считанные секунды, фрагмент обладает значительной начальной скоростью и отлетает по дуге, у упавших обломков большинство граней заостренные. При динамическом заколообразовании прорастание трещины отрыва растягивается на минуты, часы, сутки и, достигнув критических размеров, закол отрывается с практически нулевой начальной скоростью, возможно, с незначительным отклонением.

По механизму формирования все три явления идентичны. Шелушение от динамического заколообразования отличается размерами отделившихся пластин. Соответственно, разными исполнителями один и тот же процесс может трактоваться по-разному. Можно принять, что при размере обломков до $0,1 \times 0,1 \mathrm{~m}^{2}$ наблюдается шелушение, при бо́льших размерах пластин динамическое заколообразование. Шелушение более характерно для пород средней крепости и ниже. Обладая меньшей прочностью на излом, данный тип породы не способен удерживать на весу тонкие пластины значительных размеров. Стреляние можно констатировать только при непосредственном наблюдении или по результатам просмотра видеодокументов. Для минимизации разночтений в идентификации наблюдаемых процессов рекомендуются эпизодические комиссионные обследования выработок всеми сотрудниками СППГУ с привлечением работников технологических участков.

Заколы динамического происхождения отличаются от заколов, сформированных по геологическим структурам, или заколов технологического происхождения (от взрывных работ) как по форме, так и по физикомеханическим свойствам. Заколы техногенного происхождения преимущественно изометричные, с неровными плоскостями и гранями (рис. 7, 6 , внизу, и рис. 7,6 , основная масса). У заколов, формирование которых обусловлено геологическими особенностями строения массива (трещиноватостью, слоистостью и т. п.), одна или несколько граней представляют собой достаточно ровную плоскость, которая чаще всего не выглядит свежей, форма их или изометричная, или плоская с отдельными взаимно параллельными поверхностями (рис. 7, в, в центре, и рис. 7, 2). Их можно назвать условно заколами геологического происхождения. 


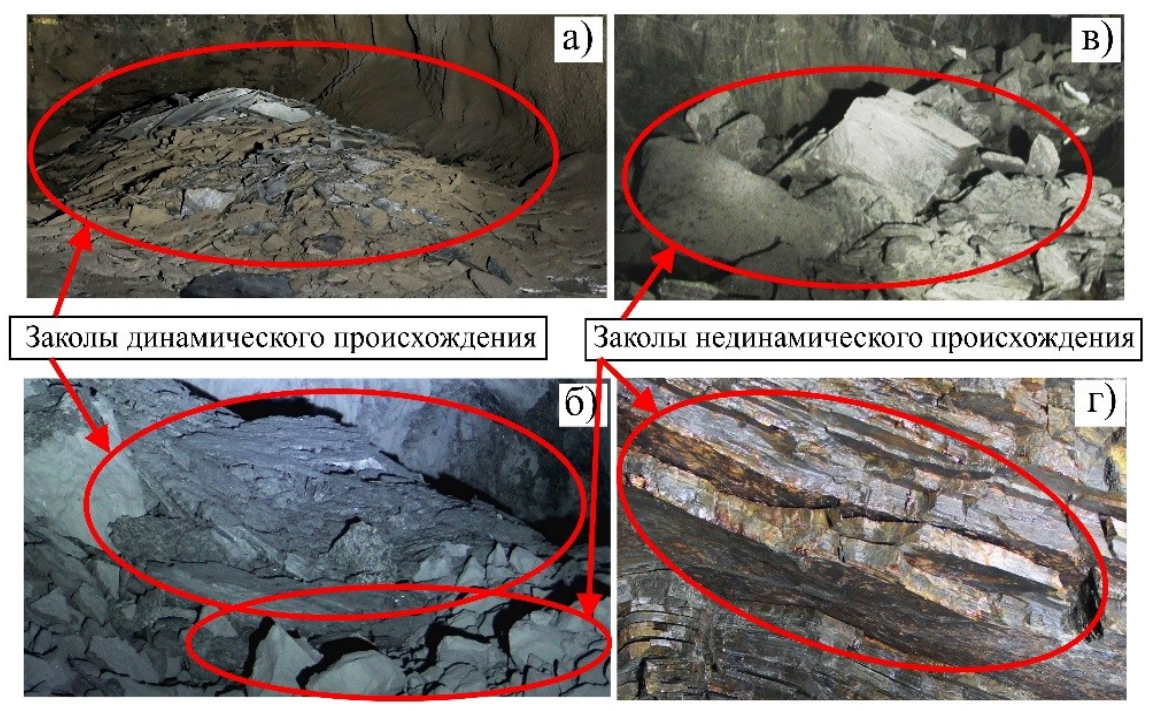

Рис. 7. Внешний вид заколов:

$a$ - заколы динамического происхождения; $\sigma$ - заколы динамического и технологического происхождения;

в - закол геологического (в центре) и обломки технологического

происхождения; г - заколы геологического происхождения

Заколы динамического происхождения имеют, как правило, выпукловогнутую форму, при незначительной, по сравнению с иными размерами, толщине. Поверхность широкой стороны может быть раковистой, что чаще обусловлено петрографо-тектоническим строением массива. Но в целом все шероховатости сглажены и обладают матовым блеском. Часть граней, по которым происходило выдавливание закола от массива, заостренные и похожи на лезвие каменного топора, другие, по которым происходил отрыв при преодолении сопротивления материала на излом под действием веса или динамического давления следом образующихся заколов, ориентированы по нормали к основной поверхности и имеют рваную, незапыленную поверхность (рис. 8). Причиной падения закола может послужить и достижение прорастающей трещиной геологического нарушения или границы пород с контрастными прочностными характеристиками, тогда грань отрыва будет определяться свойствами данной неоднородности. Так как заколы динамического происхождения сформировались в условиях высокого давления, 
то после их отделения от массива в упавших заколах сохраняется остаточное сжатие, поэтому их плотность немного выше плотности породы нетронутого массива, а звук, издаваемый при ударе по ним молотком, гораздо выше, чем у иных заколов. Наблюдались случаи растрескивания уже упавших заколов на более мелкие фрагменты за счет реализации сил внутреннего сжатия.

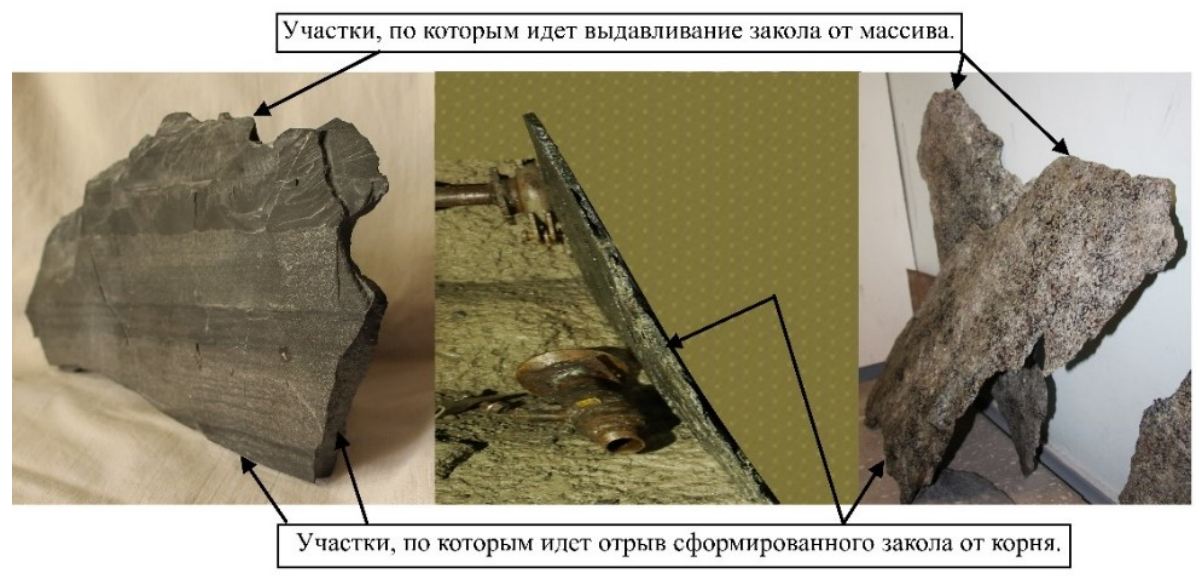

Рис. 8. Заколы динамического происхождения

Мониторинг реакции пород, способных к хрупкому разрушению, на изменение НДС позволяет четко фиксировать превышение действующими в массиве напряжениями определенного критического уровня, наблюдать миграцию очагов опасных участков при развитии горнотехнической ситуации.

Обнаружение нарушений приконтурной части выработок, их классификация, выделение из всего многообразия типов разрушений участков проявления повышенного горного давления, определение интенсивности динамических форм - главные задачи визуального наблюдения, на основе которого оценивается степень напряженного состояния массива, а также направление и ориентировочная величина действия максимальной компоненты тензора напряжений на наблюдаемом объекте исследования (месторождении, блоке, участке). Определить данные параметры можно, исходя из следующих положений.

1. Максимальные нарушения контура выработки (скважины) развиваются в плоскости, перпендикулярной результирующему вектору действующих напряжений (рис. 4). 
2. Разрушение кровли выработок свидетельствует о преобладающем действии в массиве горизонтальных (тектонических) напряжений $\sigma_{\mathrm{T}}$ (рис. $4, a$ и рис. 6).

3. Разрушение стенок горизонтальных выработок происходит при преобладающем действии в массиве вертикальных напряжений $\sigma_{\text {н }}$ (рис. $4, \sigma$ и рис. 9).

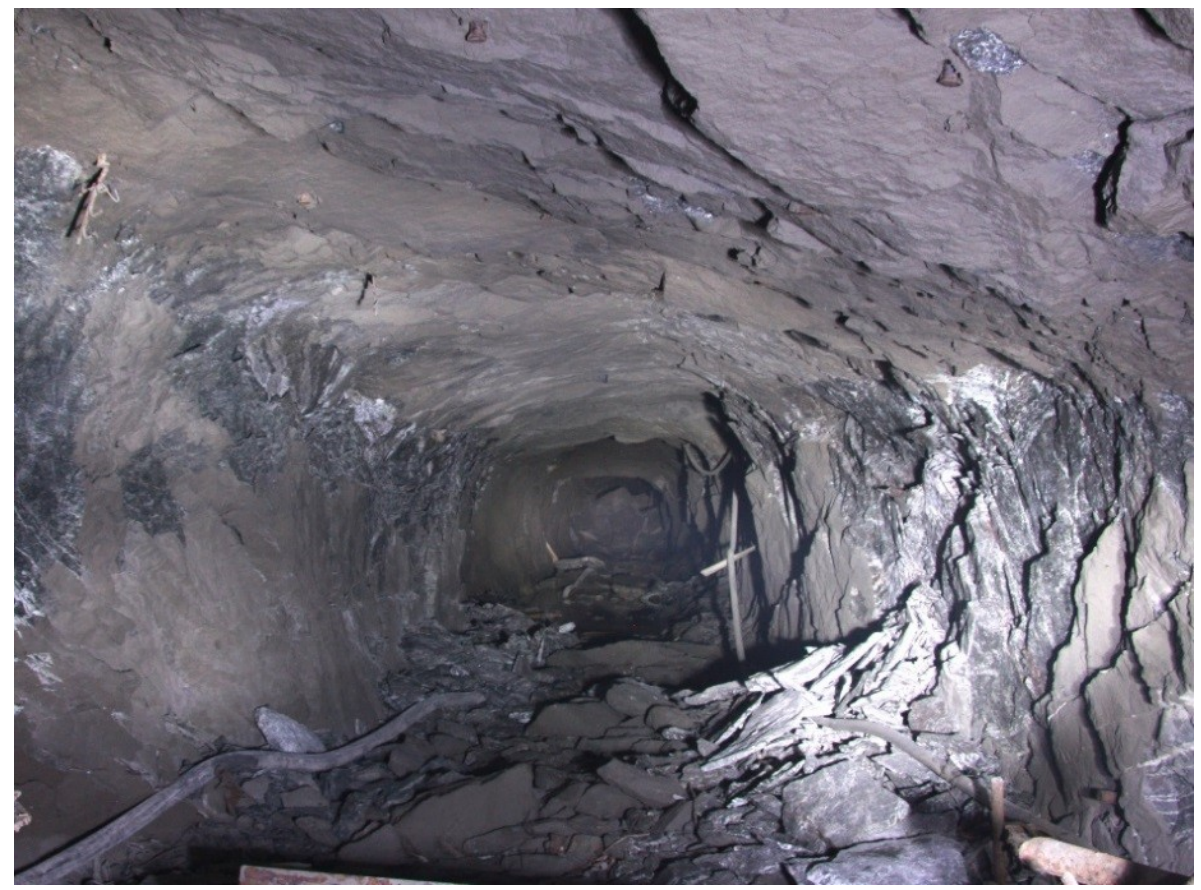

Рис. 9. Динамическое заколообразование по стенкам. Расвумчоррский рудник, разведочный квершлаг 9

4. При действии на массив гравитационной и тектонической составляющих, сравнимых по величине, что чаще проявляется в зоне опорного давления от очистных работ по вышележащему горизонту, сектор разрушения располагается в плоскости, перпендикулярной вектору действующих напряжений (рис. 4, в и рис. 5).

5. Распределение динамического заколообразования по значительному сектору сечения свидетельствует о поле напряжений, близком к 
равнокомпонентному. Контур выработки выглядит как бы искусственно сглаженным, без привычной шероховатости, что должно насторожить при оценке категории состояния и определении порядка проведения работ в данных условиях (рис. 10).

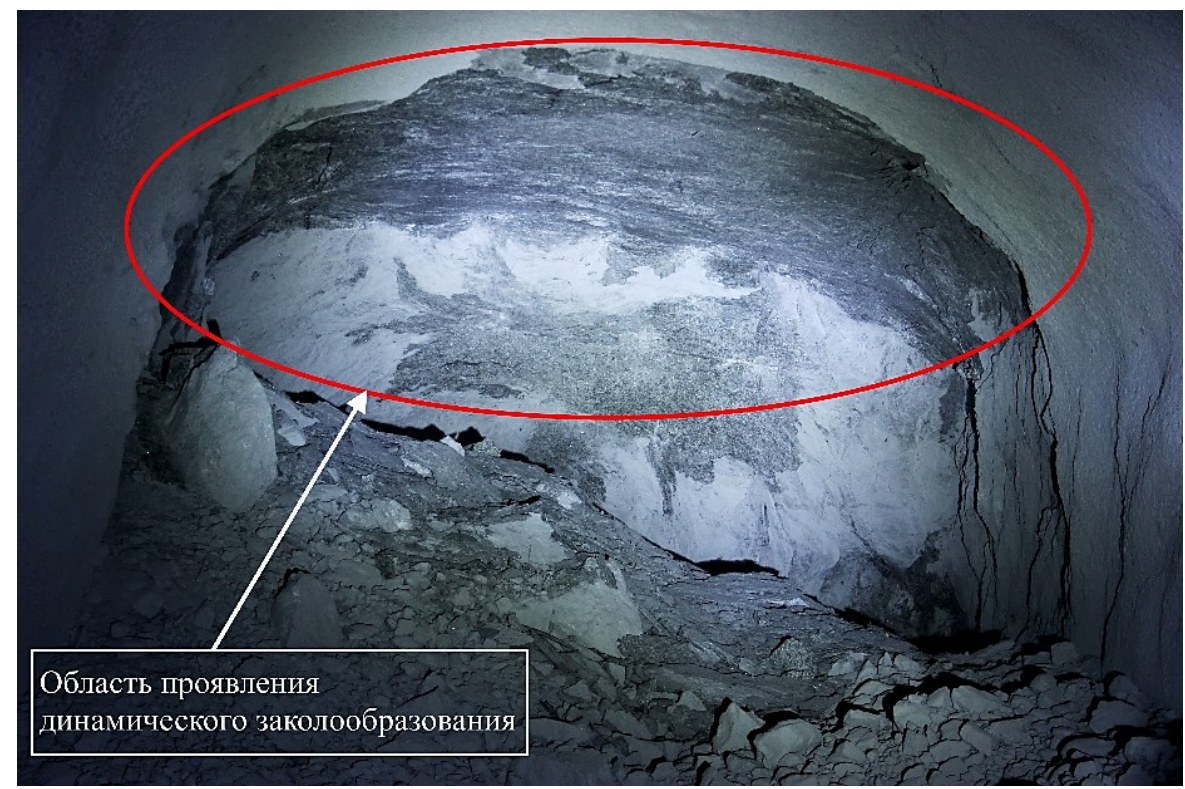

Рис. 10. Динамическое заколообразование по кровле и ее сопряжениям со стенками. Рудник «Олений ручей», автоуклон № 2

6. Наибольшая интенсивность разрушения наблюдается в выработках, пройденных перпендикулярно максимальной компоненте действующих в массиве напряжений.

7. По результатам многолетних наблюдений установлено, что нарушения приконтурной части массива выработок происходит в виде: а) шелушения при величине действующих напряжений на контуре более $0,3 \sigma_{\mathrm{c}}\left(\sigma_{1}>0,3 \sigma_{\mathrm{c}}\right)$ (рис. 5); б) интенсивного шелушения и/или динамического заколообразования при значениях $0,7 \sigma_{\mathrm{c}}>\sigma_{1}>0,5 \sigma_{\mathrm{c}}$ (рис. 6); в) интенсивного динамического заколообразования и стреляния при превышении напряжений $\sigma_{1} 0,7$ от предела прочности на сжатие $\left(\sigma_{1}>0,7 \sigma_{c}\right)$, где $\sigma_{1}-$ максимальная компонента главных напряжений, $\sigma_{\mathrm{c}}$ - прочность пород при одноосном сжатии (рис. 11). 


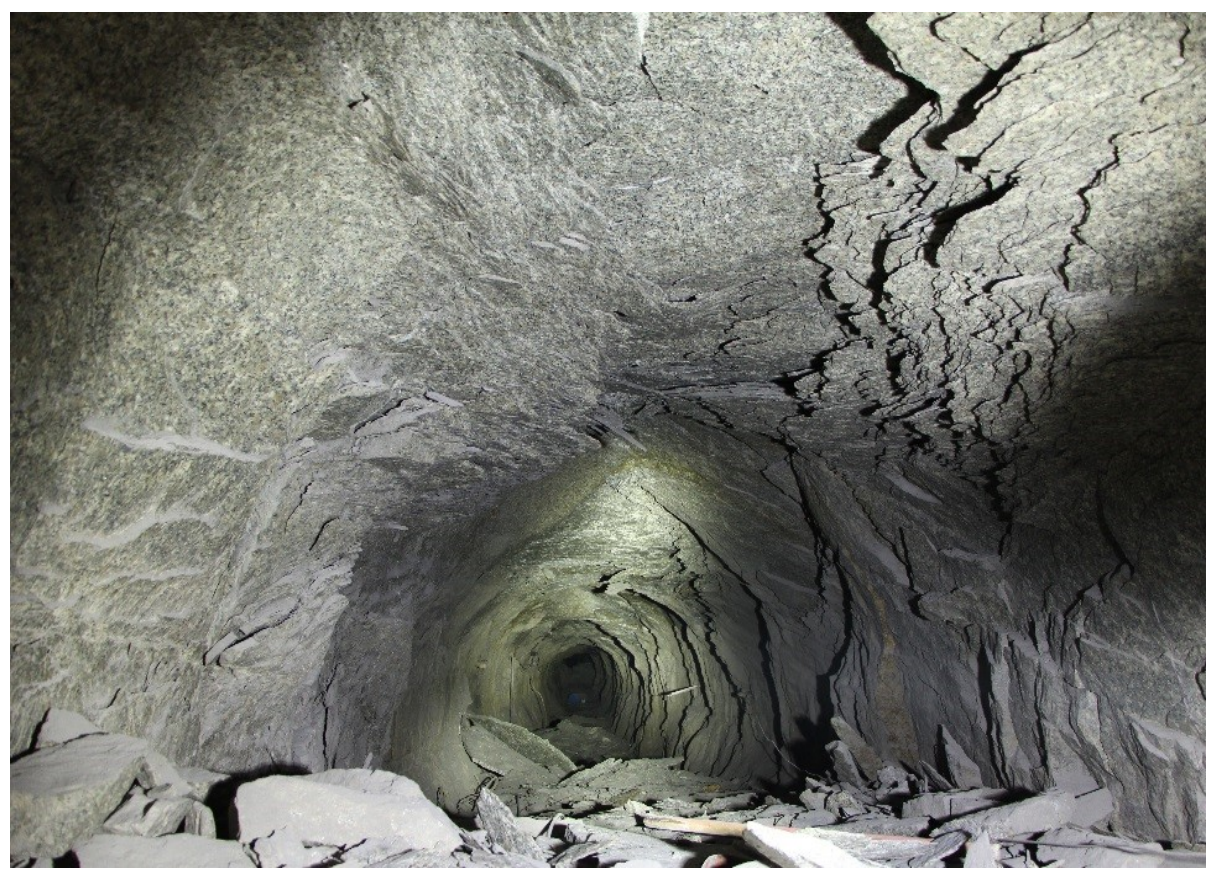

Рис. 11. Интенсивное динамическое заколообразование. Рудник «Карнасурт», восстающий-23-15

8. Сравнительная оценка интенсивности проявления внешних признаков во взаимно пересекающихся выработках (в том числе горизонтальных с вертикальными и наклонными), а также наблюдение разрушения контура пробуренных скважин (формирование «дорожек») (рис. 12) позволяют приближенно определить направление, угол наклона и величину максимальной компоненты главных напряжений $\sigma_{1}$ на участке наблюдения. 


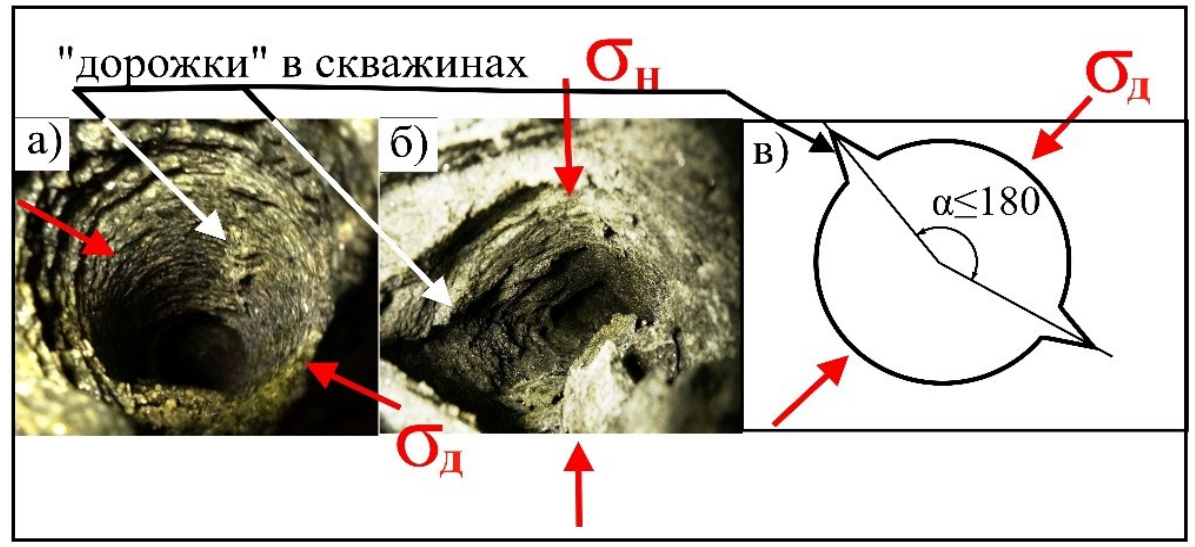

Рис. 12. «Дорожки» в шпурах: $a$ - намеченная; $\sigma$ - проработанная; 8 поперечный разрез шпура

Под термином «дорожка» понимается разрушение противоположных стенок скважины под влиянием действующих в массиве напряжений. Механизм образования «дорожек» аналогичен формированию внешних признаков удароопасности на контуре выработок с учетом масштабного фактора. Угол между плоскостями «дорожек» противоположных стенок может незначительно отличаться от развернутого (рис. 12, в).

Наличие крупных разломных структур, оперяющих их разломов, крупно- и мелкоблоковой трещиноватости существенно влияет на перераспределение напряжений и создает сложноподчиненную блочную структуру массива горных пород:

9. Протяженность мелкоблоковой трещиноватости обычно невелика, нередко ее элементы прерываются в пределах выработки, пересекая друг друга или переходя друг в друга. Раскрытие трещин часто составляет доли миллиметра или отсутствует. Часть из них заполнены вторичным материалом. Как правило, они играют роль локальных концентраторов, влияющих на незначительный участок выработки (рис. 13). Чаще всего нарушения в динамической форме наблюдаются в лежачем боку дизъюнктивных нарушений. 


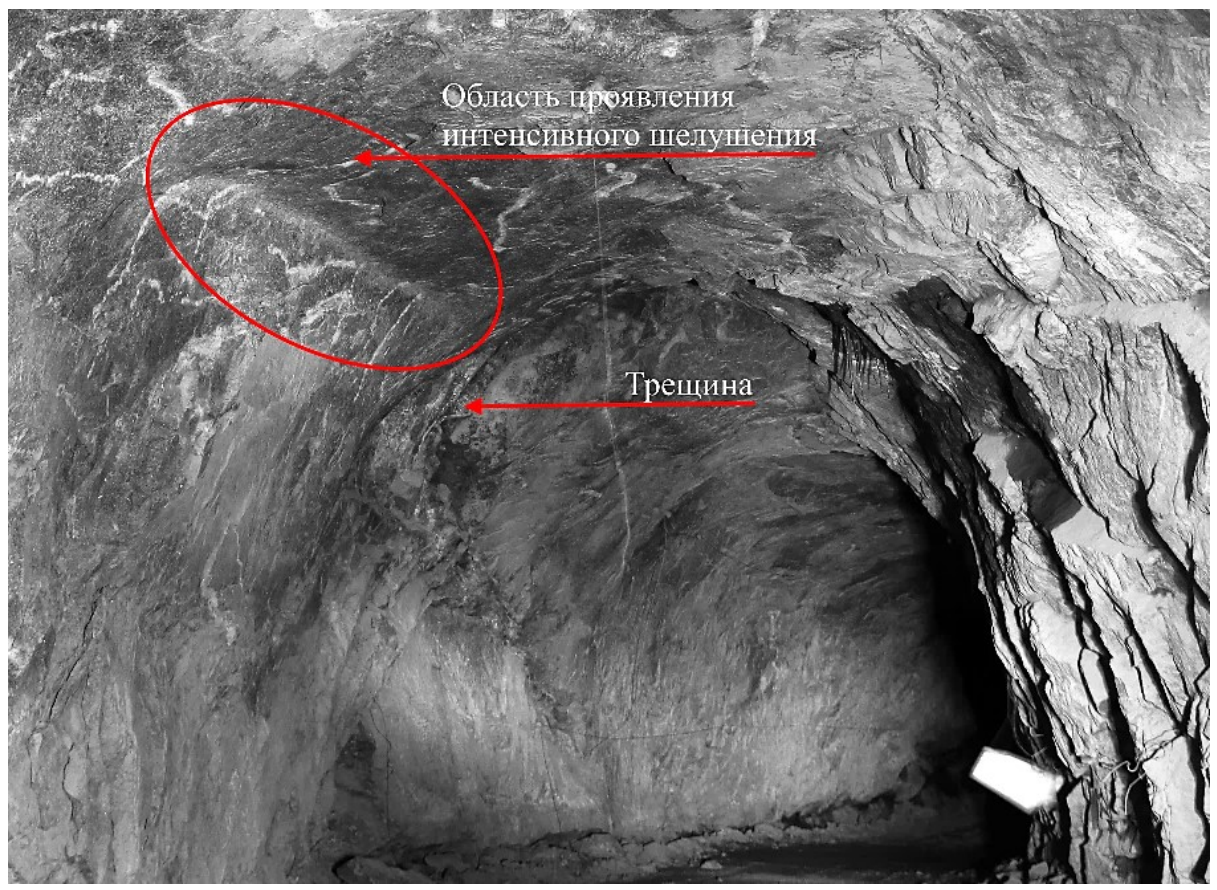

Рис. 13. Проявление интенсивного шелушения в зоне влияния тектонической трещины. Рудник «Олений ручей», воздухоподводящий уклон

10. При совпадении простирания основной системы трещин с направлением действующих напряжений в массиве $\left(\sigma_{\text {д }}\right)$ может наблюдаться процесс, внешне похожий на интенсивное динамическое заколообразование, при действующих на более низком энергетическом уровне напряжениях (рис. 14). В подобной ситуации необходимо внимательно осмотреть место и оценить степень влияния повышенного горного давления и геологического строения. Для уточнения категории удароопасности рекомендуется проведение инструментальных измерений. 


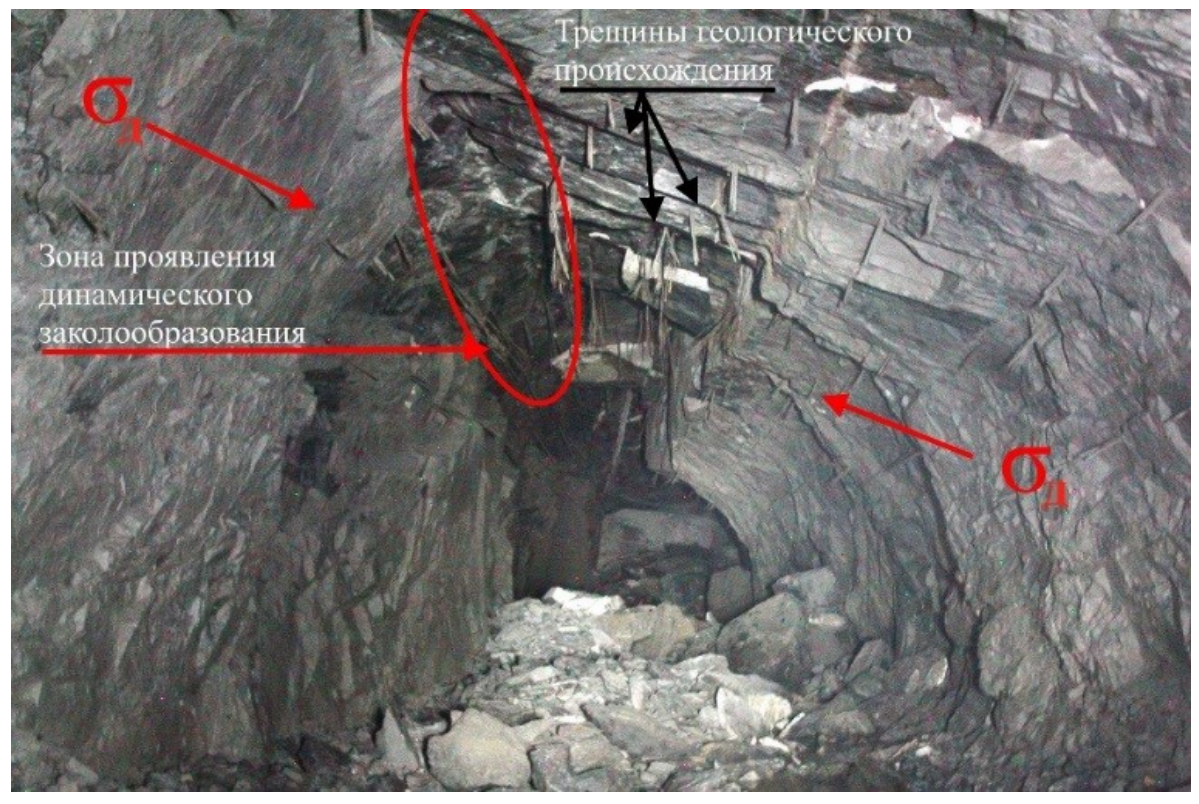

Рис. 14. Совпадение простирания основной системы трещин с направлением вектора действующих напряжений. Расвумчоррский рудник, буро-доставочный штрек-12

11. Мощные разломные зоны, выполненные слабо связанным вторичным материалом, а также разломы, представленные зоной трещиноватости со слабо развитой степенью вторичной минерализации, как правило, разделяют массив на блоки с различными геомеханическими характеристиками (рис. 15).

12. Участки массива с жесткими включениями (например, мощные монолитные мончикитовые дайки) в большей мере склонны к разрушениям в динамической форме. Их повышенные прочностные свойства позволяют сохранять видимость устойчивого состояния, в то время как в примыкающих к ним менее прочных хрупких породах (например, в апатит-нефелиновых рудах) наблюдаются выраженные внешние признаки удароопасности. При превышении предела прочности жесткого элемента вероятно его разрушение в форме горного удара (рис. 16). 


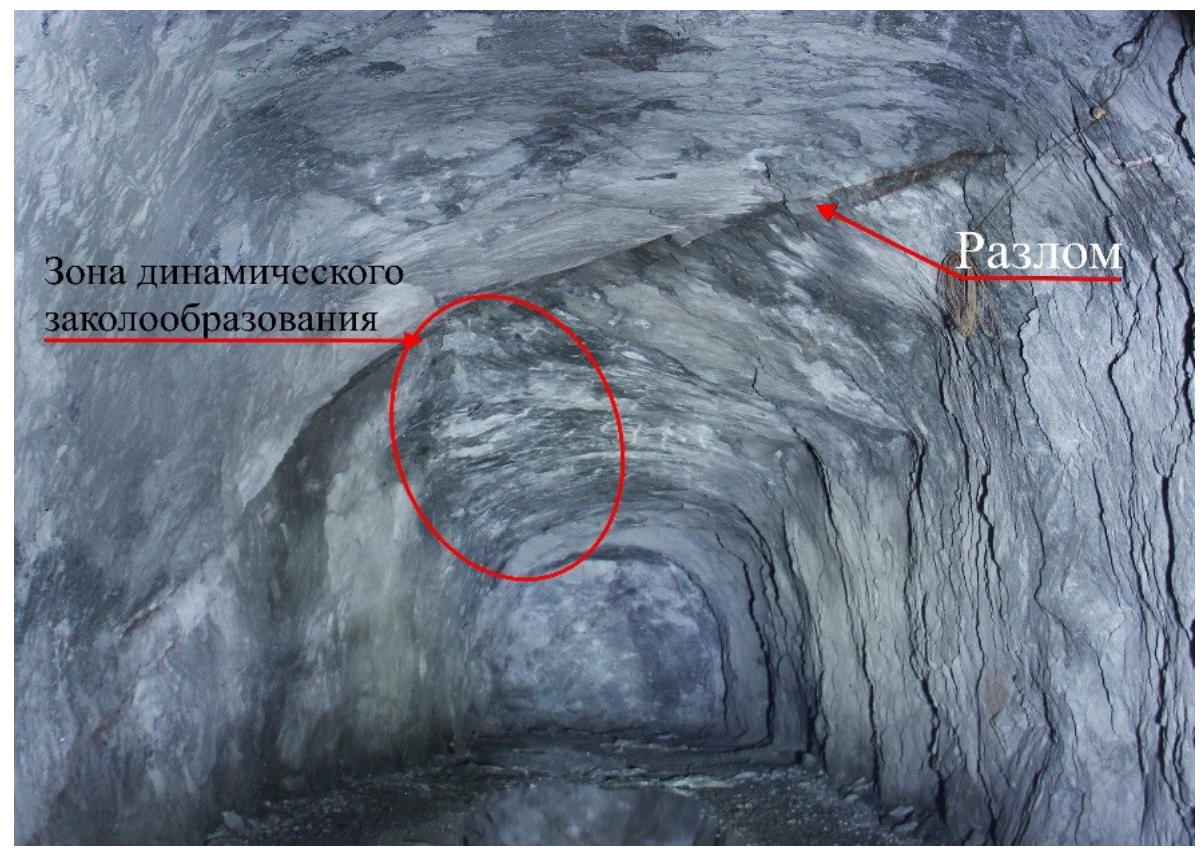

Рис. 15. Влияние разломной зоны на динамические проявления горного давления. Рудник «Олений ручей», полевой штрек +140

По степени опасности участки горного массива вокруг выработок разделяют на две категории: «Опасно» и «Не опасно» (Положение... [7]), определяемые инструментально. При существующем приборном оснащении любой контактный метод оценки удароопасности (в том числе и принятый за базовый метод дискования керна - МДК) связан с необходимостью нахождения оператора в опасной зоне достаточно длительное время.

В свою очередь, выработки находятся в разных геологических, геомеханических и горнотехнических условиях, определяемых не только строением массива, геодинамическим состоянием блока, в котором они пройдены, но и ориентацией по отношению к максимально сжимающей компоненте поля напряжения, близостью к разломной структуре и углом ее пересечения, глубиной от поверхности, рельефом, свойствами породы, зоной опорного давления от очистных работ и т. д. 


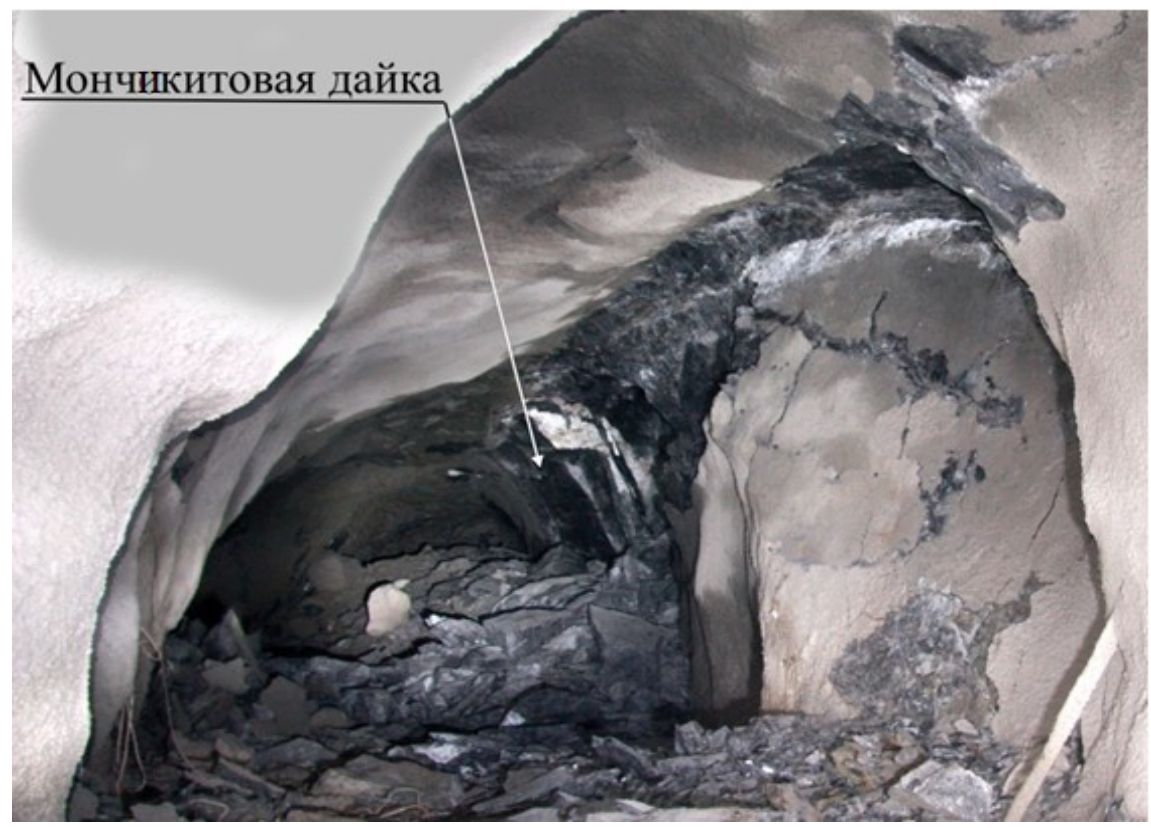

Рис. 16. Влияние жесткого включения на проявление внешних признаков удароопасности. Расвумчоррский рудник, материально-ходовой штрек-42

Оценка удароопасности участков выработок с разделением только на две категории часто является недостаточной для принятия решения о необходимости применения противоударных мероприятий и выбора вариантов крепления выработки. Для условий хибинских месторождений специалистами Горного института КНЦ РАН и АО «Апатит» на основе сопоставительного анализа данных многолетних инструментальных измерений методами МДК и контроля за разрушением контура скважин (КРС), а также визуальных наблюдений были выделены шесть категорий состояния выработок, учитывающих свойства пород, степень структурной неоднородности массива и его напряженного состояния (табл. 1). 
Классификация категорий состояния горных выработок

\begin{tabular}{|c|c|c|c|c|c|}
\hline \multirow{2}{*}{$\begin{array}{l}\text { Категория } \\
\text { состояния } \\
\text { выработок }\end{array}$} & \multicolumn{4}{|c|}{ Категория по устойчивости } & \multirow[b]{2}{*}{$\begin{array}{c}\text { Формы проявления } \\
\text { горного давления }\end{array}$} \\
\hline & $\begin{array}{l}\text { устойчивая } \\
\text { (I) }\end{array}$ & $\begin{array}{c}\text { средне- } \\
\text { устойчивая } \\
\text { (II) }\end{array}$ & $\begin{array}{c}\text { неустойчивая } \\
\text { (III) }\end{array}$ & $\begin{array}{c}\text { весьма } \\
\text { неустойчивая } \\
\text { (IV) } \\
\end{array}$ & \\
\hline $\begin{array}{c}\mathbf{A} \\
\text { (рис. 1) }\end{array}$ & $\sigma_{д} \leq 0,3 \sigma_{\mathrm{c}}$ & - & - & - & $\begin{array}{l}\text { Выработка сохраняет } \\
\text { устойчивость } \\
\text { (разрушения и } \\
\text { отслоения не } \\
\text { наблюдаются) }\end{array}$ \\
\hline $\begin{array}{c}\text { Б-1 } \\
\text { (рис. 2) }\end{array}$ & - & - & $\sigma_{\text {д }} \leq 0,3 \sigma_{\mathrm{c}}$ & - & Вывалы по трещинам \\
\hline $\begin{array}{c}\text { Б-2 } \\
\text { (рис. 3) }\end{array}$ & - & - & - & $\sigma_{\text {д }} \leq 0,3 \sigma_{\mathrm{c}}$ & $\begin{array}{l}\text { Вывалы по трещинам и } \\
\text { по слабосвязанному } \\
\text { массиву }\end{array}$ \\
\hline $\begin{array}{c}\text { В } \\
\text { (рис. 4) }\end{array}$ & \multicolumn{3}{|c|}{$0,3 \sigma_{\mathrm{c}}<\sigma_{\text {д }} \leq 0,5 \sigma_{\mathrm{c}}$} & - & $\begin{array}{l}\text { Постепенное отслоение } \\
\text { по трещинам. } \\
\text { Постепенное хрупкое } \\
\text { разрушение пород на } \\
\text { контуре в виде } \\
\text { шелушения, } \\
\text { незначительного } \\
\text { динамического } \\
\text { заколообразования }\end{array}$ \\
\hline $\begin{array}{c}\Gamma \\
\text { (рис. } 5-7 \text { ) }\end{array}$ & \multicolumn{3}{|c|}{$0,5 \sigma_{\mathrm{c}}<\sigma_{\text {д }} \leq 0,7 \sigma_{\mathrm{c}}$} & - & $\begin{array}{l}\text { Интенсивное } \\
\text { шелушение, } \\
\text { динамическое } \\
\text { заколообразование }\end{array}$ \\
\hline $\begin{array}{c}\text { Д } \\
\text { или } \\
\text { «Опасно» } \\
\text { (рис. } 8,9 \text { ) }\end{array}$ & \multicolumn{2}{|c|}{$\sigma_{\text {д }}>0,7_{\sigma}$} & - & - & $\begin{array}{l}\text { Стреляние и } \\
\text { интенсивное } \\
\text { динамическое } \\
\text { заколообразование, } \\
\text { возможны микроудары и } \\
\text { горные удары }\end{array}$ \\
\hline
\end{tabular}

Примечание: Нумерация рисунков соответствует номерам фотографий, приведенных в приложении 1 , где $\sigma_{\text {д }}$ - действующие напряжения; $\sigma_{c}$ прочность пород на одноосное сжатие. Категория по устойчивости определяется в соответствии с Указаниями... [5, 6]. Категория состояния «Д» определяется по результатам визуального обследования, а категория удароопасности «Опасно» - инструментальными методами. 
Применение на практике в течение нескольких десятилетий данной классификации доказало ее практическую целесообразность. При определенной модификации она может быть применена (и применяется) на других предприятиях, разрабатывающих месторождения подземным способом.

Оперативная оценка состояния выработки может быть выполнена при сопоставлении наблюдаемых процессов с их описанием, представленным в табл. 2.

Таблица 2

Оперативная оценка категории состояния приконтурной части выработок по характеру проявления внешних признаков удароопасности

\begin{tabular}{|c|c|c|}
\hline $\begin{array}{l}\text { Категори } \\
\text { я } \\
\text { состояни } \\
\text { я }\end{array}$ & $\begin{array}{c}\text { Характеристика } \\
\text { (после длительно отстоя (более } 2-3 \text { суток) }\end{array}$ & $\begin{array}{r}\text { Периодичность } \\
\text { обезопашивания }\end{array}$ \\
\hline $\mathbf{A}$ & Новых разрушений нет & При необходимости \\
\hline Б-1 & Вывалы по естественным трещинам & То же \\
\hline Б-2 & Вывалы по естественным трещинам и по сплошности породы & $\begin{array}{l}\text { Работы выполняются } \\
\text { после крепления }\end{array}$ \\
\hline B & $\begin{array}{l}\text { Постепенное отслоение по трещинам, шелушение, } \\
\text { незначительное (очаговое) динамическое заколообразование, } \\
\text { возможны отдельные потрескивания. Время созревания заколов } \\
\text { после обезопашивания - дни, недели }\end{array}$ & При необходимости \\
\hline$\Gamma$ & $\begin{array}{l}\text { Шелушение, динамическое заколообразование, слышно } \\
\text { периодическое (от одного до нескольких раз в минуту) } \\
\text { потрескивание, эпизодически громкие хлопки. Время } \\
\text { созревания заколов после обезопашивания } \\
\text { - 4-8 часов. В шпурах наблюдаются слабо намеченные } \\
\text { «дорожки». Через 6-12 часов после отпала интенсивная стадия } \\
\text { процесса, как правило, затухает }\end{array}$ & $\begin{array}{l}\text { В начале смены и при } \\
\text { необходимости в } \\
\text { середине смены }\end{array}$ \\
\hline Д & $\begin{array}{l}\text { Интенсивное динамическое заколообразование, не затухающее } \\
\text { несколько суток после отпала, стреляние. Сопровождается } \\
\text { интенсивным потрескиванием различной интенсивности, } \\
\text { громкими хлопками. В шпурах наблюдаются явно выраженные } \\
\text { «дорожки», эллипсовидная форма «стаканов» от взрывных } \\
\text { скважин. Длительность процесса от } 2 \text { и более суток, миграция } \\
\text { очагов разрушения, увеличение длины «дорожек» в скважинах. } \\
\text { Время созревания заколов - 1-4 часа }\end{array}$ & $\begin{array}{l}\text { Работы выполняются } \\
\text { после приведения } \\
\text { участка в } \\
\text { неудароопасное } \\
\text { состояние }\end{array}$ \\
\hline
\end{tabular}




\section{3. ОРГАНИЗАЦИЯ И ВЫПОЛНЕНИЕ ВИЗУАЛЬНЫХ НАБЛЮДЕНИЙ}

\section{1. Цели и задачи, периодичность выполнения работ}

Основная цель визуальных наблюдений - выявление участков выработок с внешними признаками удароопасности и их классификация по категориям состояния (табл. 1, 2). Виды и рекомендуемая периодичность выполнения визуальных наблюдений определяются Указаниями... [5, 6]. Наиболее характерными из них являются:

- полное обследование всех действующих выработок, доступных для посещения, включая закрепленные и расположенные вне зоны влияния очистных работ (рекомендуется выполнять не реже одного раза в полгода);

- обследование всех выработок, находящихся в проходке (рекомендуется выполнять ежемесячно);

- обследование выработок, находящихся в проходке, где наблюдается динамическое заколообразование или интенсивное шелушение (категории состояния — «Г» или «Д», рекомендуется контролировать ежесуточно);

- проведение обследования при получении информации об обнаружении новых участков повышенного горного давления или при усилении проявления внешних признаков удароопасности на объектах наблюдения (в течение суток с момента получения сообщения);

- после каждого массового взрыва (при этажной системе отработки) обследование выработок, расположенных на расстоянии не менее 50 м от границы отбитой секции. Проводится не ранее суток (время, необходимое для завершения процесса перераспределения напряжений после изменения конфигурации очистного пространства) и не позднее трех суток после отбойки, в противном случае все изменения могут оказаться под креплением. Для проведения последующего сравнительного анализа рекомендуется выполнить дополнительное обследование выработок данного района перед производством массового взрыва.

Оформление и передача информации о результатах визуального обследования в соответствующие структурные подразделения и руководству горного предприятия осуществляются в соответствии с требованиями Указаний... [5, 6]. В случае обнаружения выработок с категорией состояния «Д» или установления категории удароопасности «Опасно» инструментально — в течение суток. 


\section{2. Техника безопасности}

Полевые работы по визуальному обследованию в преобладающем числе случаев выполняются в течение длительного времени в выработках, где наблюдаются проявления горного давления в динамической форме (категория состояния «Г» или выявленная в ходе наблюдений категория «Д»). Для обеспечения безопасных условий труда при производстве ниже перечисленных операций специалистами СППГУ, выполняющими измерения в опасных условиях, рационального использования их рабочего времени, сохранности первичной документации рабочее звено должно состоять из двух человек, один из которых назначается старшим.

Допуск в выработки, где будут выполняться визуальные обследования, осуществляет мастер участка, если иное не прописано в Инструкции... [8]. Рабочее место должно соответствовать нормам ФНиП-2013 [9] и требованиям, изложенным в Инструкции... [8]. Основные правила выполнения работ в выработках с внешними признаками удароопасности изложены в Указаниях... $[5,6]$, где приведены лишь некоторые рекомендации, которые наработаны в ходе многолетних наблюдений.

1. Перед подходом к месту выполнения работ необходимо внимательно осмотреть подошву выработки. Там, где концентрация обломков больше, наиболее вероятно падение новых (рис. 17).

2. Тщательно осмотреть кровлю и стенки выработки, при необходимости произвести обезопашивание. Так как высота выработок, где применяется самоходная техника, превышает 3,5 м, обезопашивание должно выполняться специально обученным персоналом технологического участка (п. 86, ФНиП2013 [9]).

3. Внимательно прислушаться к наличию потрескивания, которое обычно сопровождает проявление горного давления в динамической форме, оценить его силу и интенсивность.

4. Наблюдения в выработках с явно выраженными признаками горного давления рекомендуется проводить при отсутствии технологического шума (бурения, близко работающих вентиляторов и т. п.).

5. Сопоставляя наблюдения с данными, приведенными в табл. 2, оценить категорию состояния выработки. По форме обломков, степени их запыленности и объему упавших заколов можно судить о природе и времени их формирования. В зависимости от предварительно оцененной категории состояния определяется периодичность обезопашивания или допустимое время пребывание в данных условиях. 


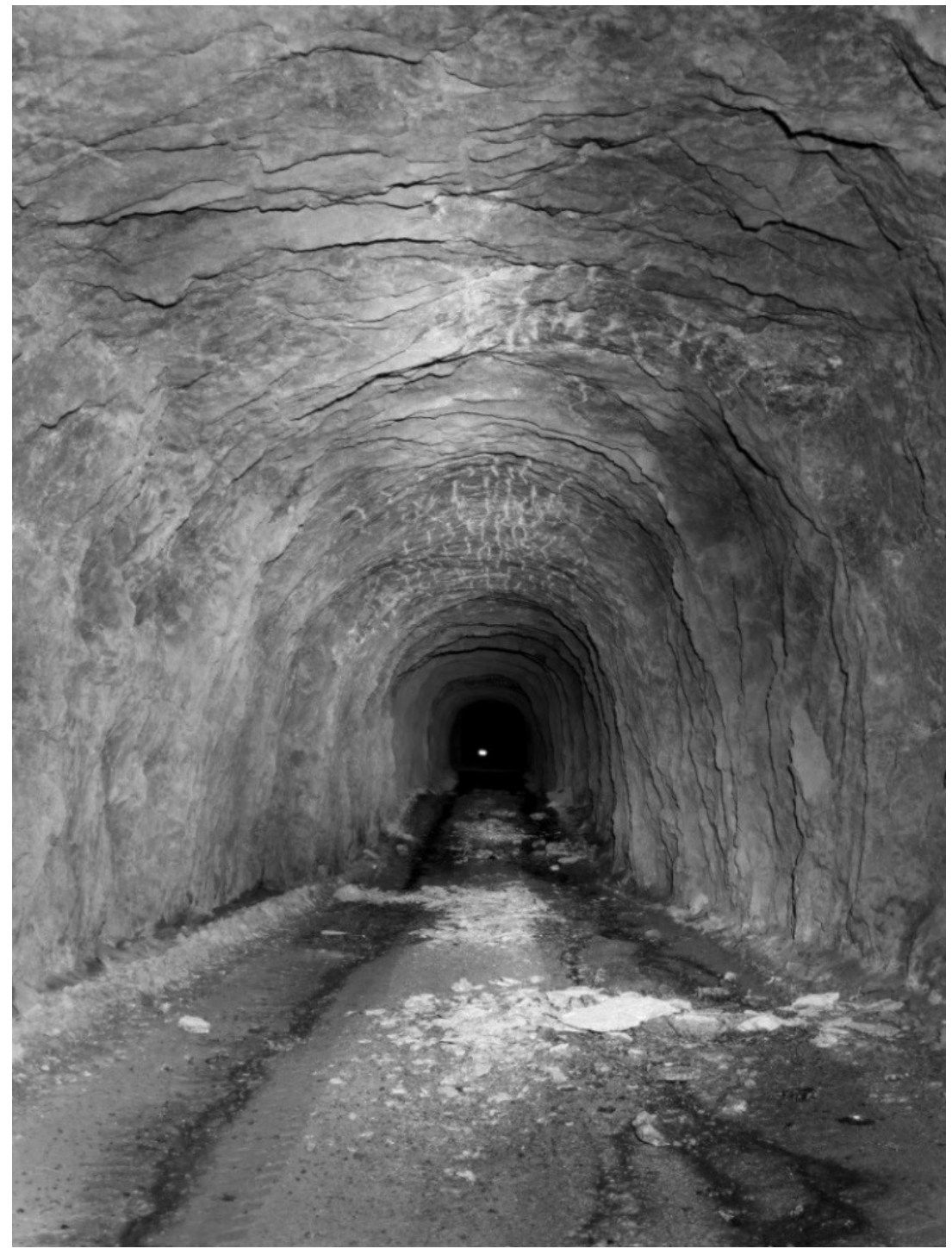

Рис. 17. Оценка безопасного маршрута прохождения выработки по обломкам породы на подошве. Рудник «Олений ручей», воздухоподводящий уклон 
6. Нельзя недооценивать заколы в зоне отжима. Энергия их формирования, как указывалось выше, значительно меньше, но отделяются они без привычного для динамического заколообразования в зоне сжатия громкого треска, а размеры их значительны (рис. 3), падают они после полного отделения от массива тихо, что повышает их опасность.

7. При выполнении работ в выработке категории «Г» или предполагаемой категории «Д» необходимо соблюдать дистанцию между членами звена не менее 5 м.

8. В выработках, где установлены степень удароопасности «Опасно» или категория состояния «Д» (табл. 1, 2), проведение каких-либо работ, кроме приведения данного участка в неудароопасное состояние, запрещено. Допускается визуальный осмотр, зарисовка или фотосъемка обследуемого участка из безопасного места или из-под козырька механического транспортного средства.

\section{3. Оборудование}

Для выполнения работ по визуальному обследованию горных выработок требуется.

1. Выкопировка с плана горных работ (далее - выкопировка) в масштабе не мельче $1: 1000$ с маркшейдерскими точками, пополненная данными о проходке и отбойке по данному горизонту, нумерацией разрезов и магистралей. В заголовке указывается название предприятия (рудника, шахты или месторождения), номер блока, высотная отметка и дата проведения обследования. Следует избегать излишней загруженности рабочей графики данными о проектных контурах, креплении, геологии и т. п.

2. Планшет для закрепления выкопировки, которая крепится с помощью зажимов или резинового хомута. Для удобства применения (чтобы освободить руки) верх планшета закрепляется с помощью шнура на шее, нижнее ребро упирается в поясной ремень или крепится другим шнуром к поясу.

3. Пикетажный журнал (пикетажка), служащий для внесения данных, которые невозможно отобразить на выкопировке, не перегружая ее. Рекомендуется в качестве образца использовать практику ведения подобной документации участковыми геологами, где перед выходом в масштабе $1: 20$ прорисовываются подошва и стенки (желательно с указанием пикетов). Другая страница оставляется для отображения эскизов и пояснений (рис. 18). На обложке указываются название предприятия и службы, фамилия, имя и отчество исполнителя, дата начала и окончания ведения журнала. На второй странице перечень выработок, обследование которых вошло в данную пикетажку, с указанием блока и горизонта. На текущей странице в 
обязательном порядке указывается дата проведения обследования. Для каждой выработки выделяется количество места в соответствии с ее протяженностью по проекту. Такой способ увеличивает расход пикетажек, но удобен при проведении аналитической оценки.

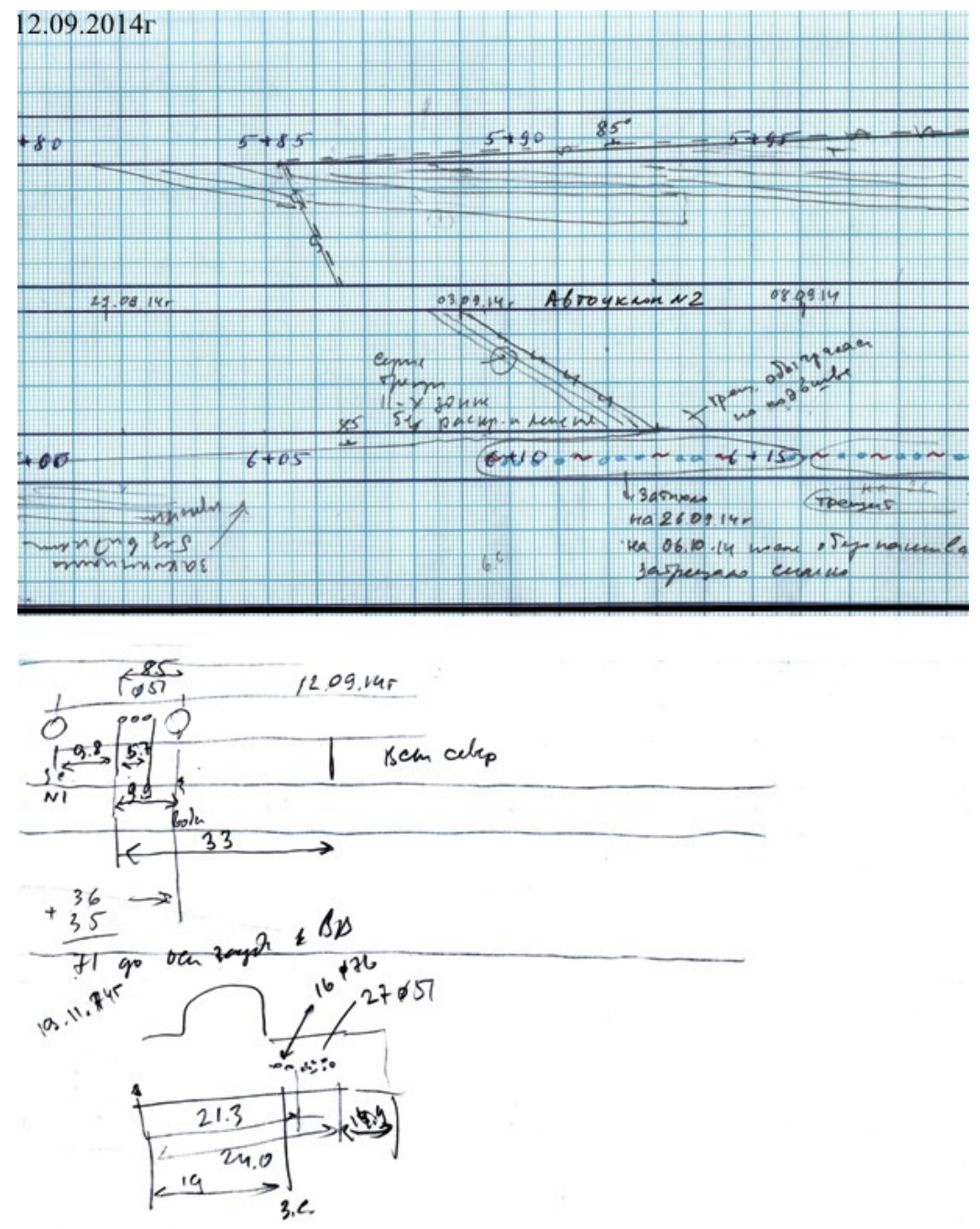

Рис. 18. Пикетажный журнал 
4. Карандаш, желательно мягкий, механический с толщиной стержня 0,5 мм.

5. Линейка с яркой шкалой длиной 15-20 см, которая, кроме основного назначения, используется в качестве масштабного элемента при фотосъемке.

6. Лазерная рулетка для привязки участков, не доступных для непосредственного контакта по условиям безопасности, с функцией измерения углов наклона для съемки сечений выработки и описания элементов залегания геологических структур.

7. Фотоаппарат с функцией Zoom, поворотным экраном ЖК, ручной фиксацией диафрагмы не менее 1 мин, пультом дистанционного управления, физическим размером матрицы не менее $22 \times 15$ мм. Рекомендуется брать с собой фотоаппарат при каждом обследовании. Практика показала, что, как только фотоаппарат оставался на поверхности, безвозвратно терялась полезная, но незафиксированная информация. Фотографии - незаменимые документы при камеральной обработке, разборе текущей ситуации, подготовке аналитических записок и проведении ретроспективного анализа.

8. Штатив для закрепления как фотоаппарата, так и лазерной рулетки (рис. 19). Качество фотоснимков с руки, учитывая необходимость в длительной выдержке, намного хуже, чем со штатива.

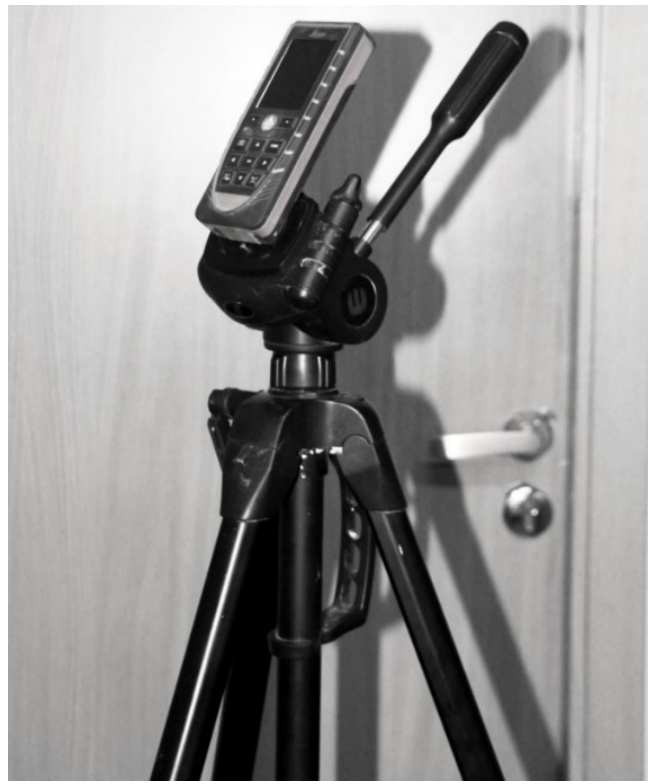

Рис. 19. Крепление лазерной рулетки к треноге 


\section{4. Порядок выполнения работ и первичная документация}

Обследование целесообразно проводить в два этапа: сначала описываются выработки с фотосъемкой характерных участков и при необходимости намечаются места съемки сечений с пометкой на выкопировке их предполагаемого расположения. Съемка сечений выполняется в отдельный выход.

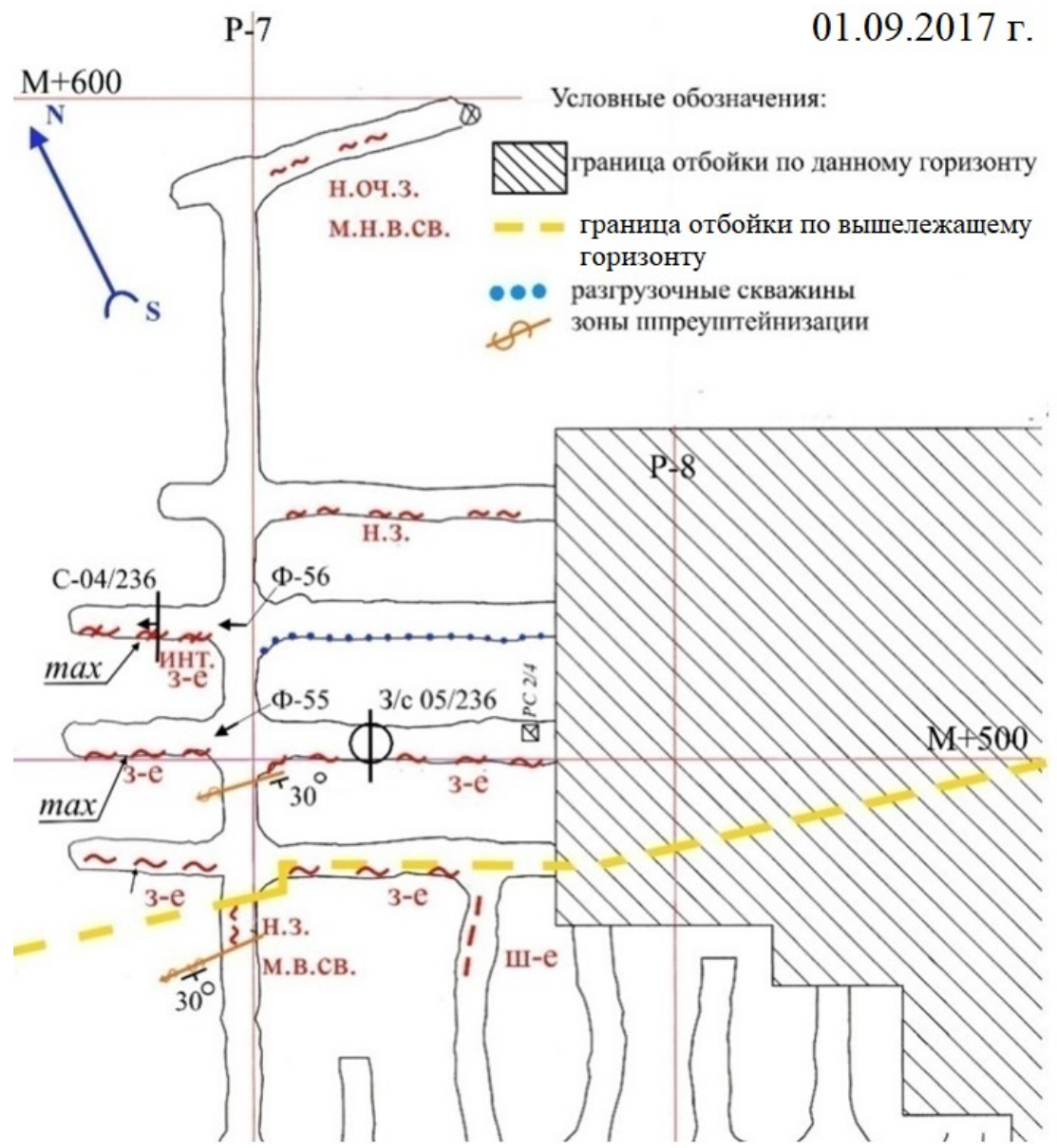

Рис. 20. Фрагмент чистовой выкопировки из плана 
Все участки, где обнаружены внешние признаки, наносятся на выкопировку условными знаками (приложение 3) с привязкой рулеткой или тарированными шагами к маркшейдерским точкам, сопряжениям (осям) ближайших выработок или иным объектам, обозначенным в масштабе на плане (рис. 20).

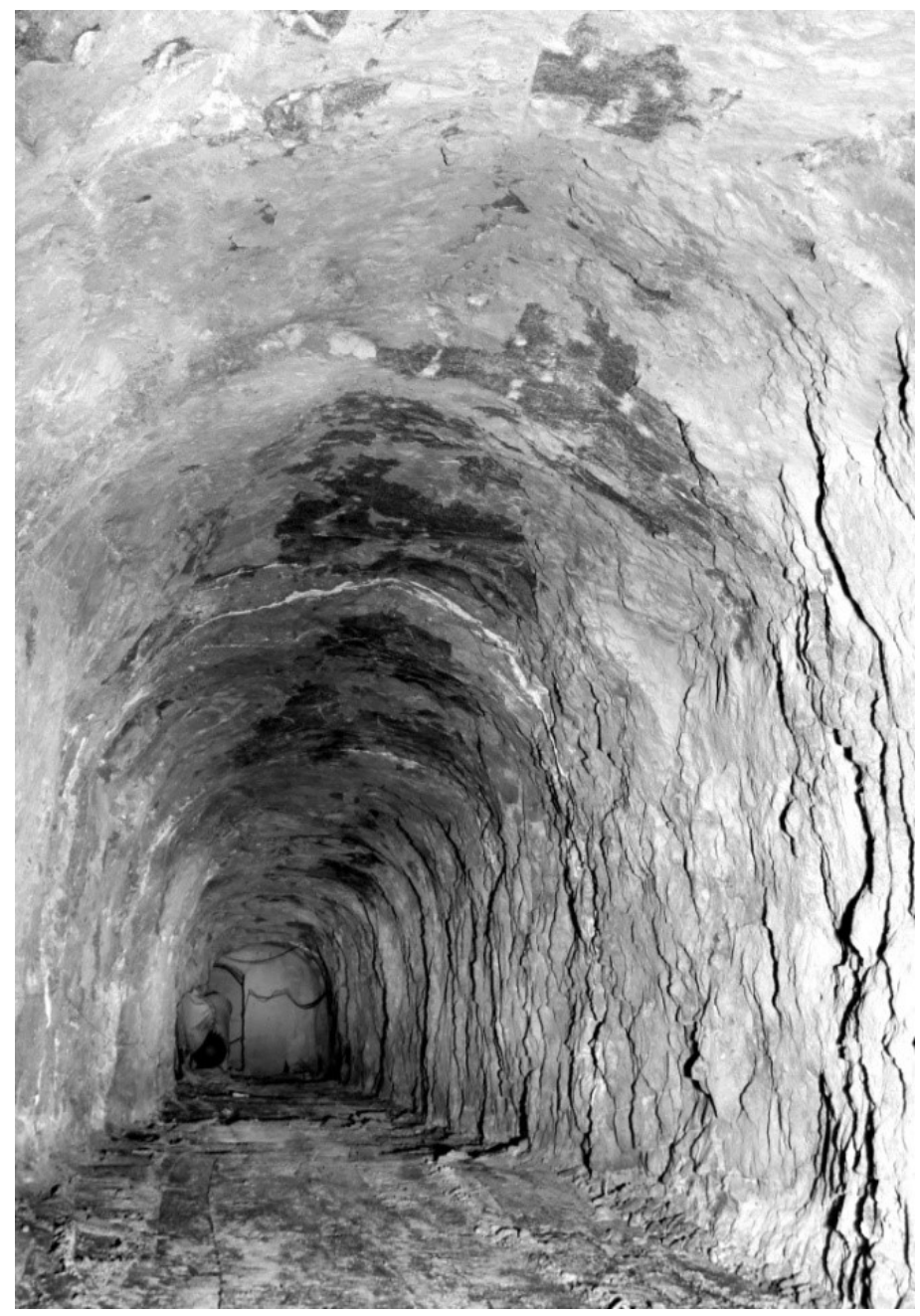

Рис. 21. Очаговое динамическое заколообразование. Рудник «Олений ручей», воздухоподводящая штольня 
Отмечаются начало и окончание участка с проявлением внешних признаков удароопасности, их классификация, интенсивность (в условных обозначениях), область максимального проявления. Рекомендуется выделять участки с намеченными, слабо выраженными формами или проявлениями очагового характера, когда признаки проявляются отдельными, но достаточно упорядоченными пятнами (рис. 21), а также запыленные фрагменты, указывающие на то, что здесь в прошлом проявлялось повышенное горное давление. Проявления, наблюдаемые в разных элементах сечения (кровле, сопряжении, стенках), также отмечаются в соответствии с условными обозначениями (приложение 3). Все проявления внешних признаков дополняются пометками их характера и интенсивности в соответствии с приложением 1. Подобное документирование является важнейшей информацией при проведении реального, перспективного и ретроспективного анализов геодинамического состояния массива.

Особо тщательно осматривают и заносят в пикетажный журнал существенные элементы геологического строения: крупные разломы и трещины, степень их раскрытия, характер заполнения, пересечение выработки породами с контрастными физико-механическими свойствами (дайки, жилы, контакты порода - руда), их элементы залегания.

Компас в подземных условиях часто дает большую погрешность, поэтому для отображения простирания точки пересечения структур с подошвой выработки привязываются при помощи рулетки. Если состояние рабочего места не противоречит условиям безопасности, при выполнении данной операции удобнее пользоваться ленточной рулеткой. Угол падения определяют с помощью угломера лазерной рулетки. Также отмечается наличие маркирующих элементов, позволяющих оценить амплитуду смещения берегов дизъюнктивных нарушений. Документация трещин с зеркалами и бороздами скольжения сопровождается их детальным описанием (рис. 22). 


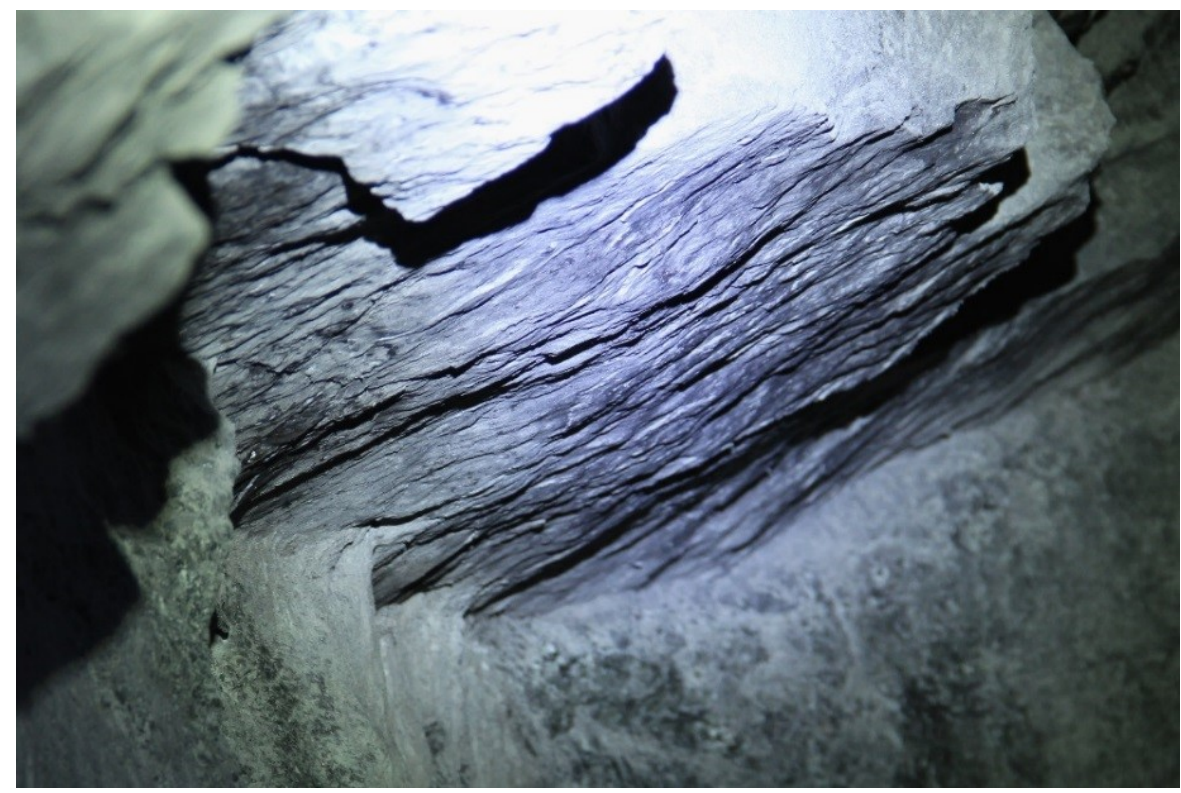

Рис. 22. Зеркало скольжения. Рудник «Олений ручей», автоуклон № 2

На выкопировке также отмечается расположение замерных станций, скважин (шпуров) любого назначения, если в них обнаружены «дорожки» (рис. 12), выполняется глазомерная оценка их протяженности, расположения максимума разрушений. Угол наклона скважины и «дорожки» измеряется лазерной рулеткой. Полученные данные заносятся в пикетажный журнал.

Там, где выполнено бурение разгрузочных скважин (ОРЩ), отмечаются характер разрушения межскважинных целиков и степень проработки строчки скважин (рис. 23). Необходимо обращать внимание на наличие отступлений от параметров бурения, указанных в паспорте бурения ОРЩ: на расстояние между скважинами, их глубину, угол заложения строчки и скважин и т. п. (рис. 23, a) 


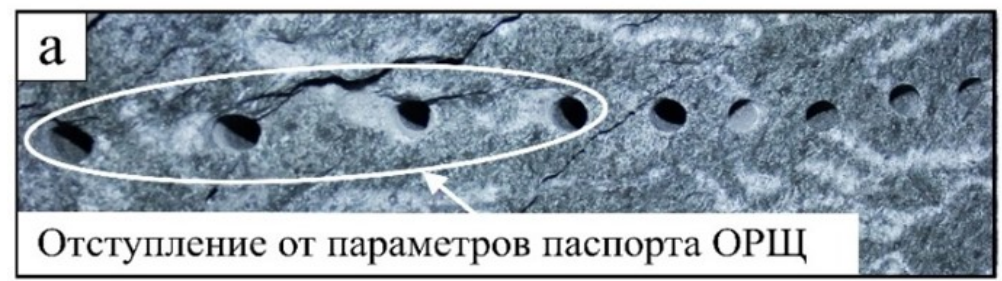

Непроработанные межскважинные целики

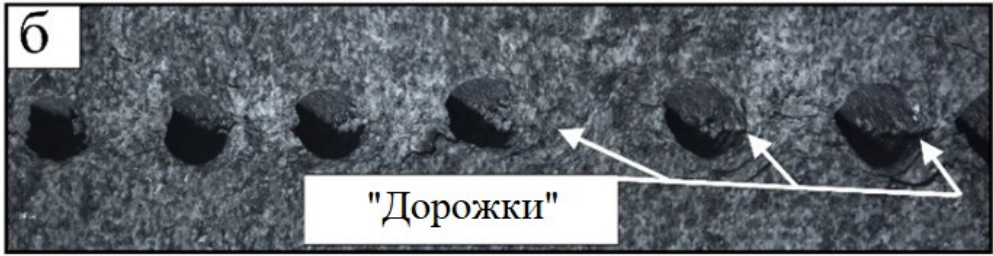

Начальная стадия разрушения межскважинных целиков

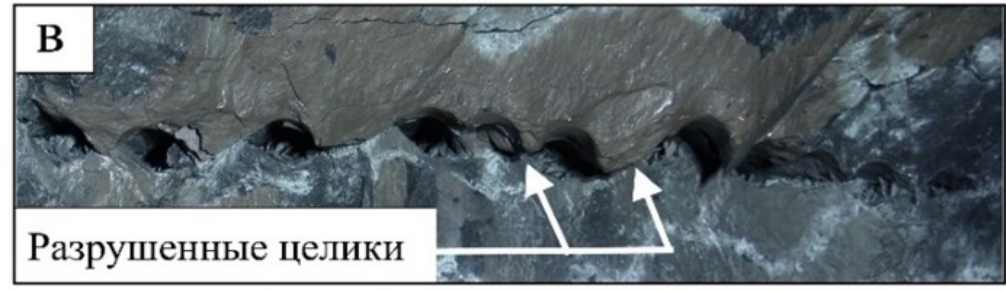

Проработанные межскважинные целики

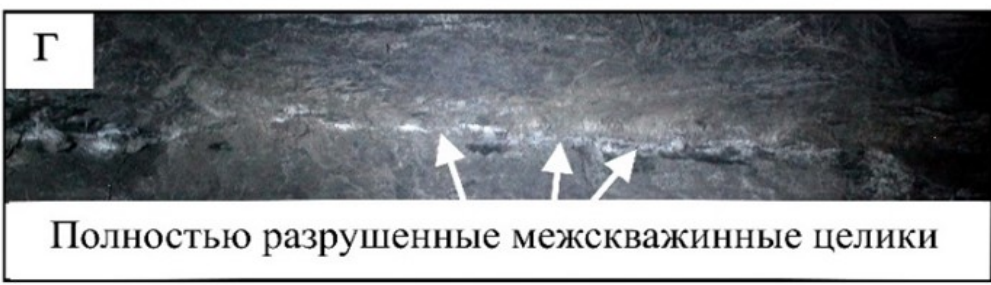

Полностью проработанная разгрузочная строчка

Рис. 23. Различные состояния межскважинных целиков в разгрузочной строчке скважин 
На участках выработок, где наблюдались наиболее выраженные формы разрушений, выполняются фотосъемка, зарисовка или съемка сечений (рис. 24). На выкопировке отмечаются: точка установки фотоаппарата, направление съемки и номер кадра; линия снятого сечения или выполненного эскиза, направление взгляда съемщика и порядковый номер (рис. 20). В нумерации сечений удобнее указывать его номер и отметку горизонта. Рекомендуется выполнять фотосъемку существенных разломных структур.

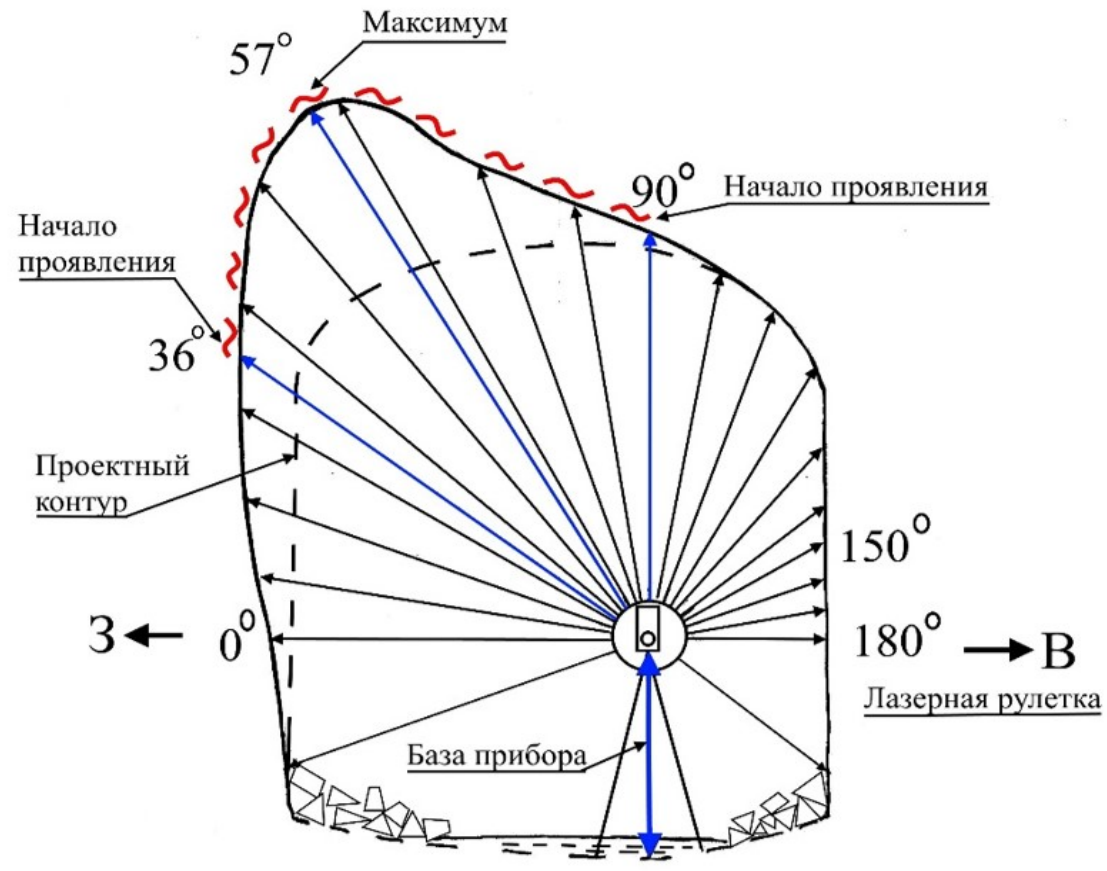

Условные обозначения:

ح - зона проявления внешних признаков удароопасности

$36^{\circ}$ - угол наклона луча лазерной рулетки

Рис. 24. Схема съёмки сечений 
Съёмка сечений выполняется лазерной рулеткой, устанавливаемой на штативе (рис. 18). Перед установкой штатива необходимо убедиться в безопасном состоянии контура выработки.

Штатив устанавливается по возможности (если это не противоречит условиям безопасности) в центре выработки, плоскость вращения рулетки должна располагаться перпендикулярно оси выработки. Для проверки правильности установки рулетки несколько раз прогоняют луч по кругу. Измерения угла наклона и расстояния до контура в зоне существенной нарушенности производятся с шагом $10^{\circ}$. Необходимо контролировать, чтобы точка на рулетке, от которой берутся отсчеты, совпадала с осью ее вращения, или учесть это при обработке данных съемки.

Результаты заносятся в таблицы, бланки которых заготавливаются заранее (пример приведен в табл. 3). При этом указываются: база прибора; расстояние от оси вращения лазерной рулетки до подошвы; характер подошвы выработки и ее сопряжения со стенками (скала, порода, вода и т. п.); начало и окончание участка с внешними признаками и расположение максимума их проявлений, что не всегда совпадает с зоной максимального разрушения; ориентация стенок по сторонам света.

Если точки начала, окончания или максимума проявления разрушения не кратны $10^{\circ}$, более точные значения указываются в знаменателе ближайшего значения (табл. 3).

Рекомендуется дополнительно делать эскиз, на котором, кроме отметки внешних признаков удароопасности, отмечаются структурные и петрографические неоднородности массива, оказывающие существенное влияние на расположение максимума разрушения и состояние контура в целом (рис. 25).

Если замерная станция предполагается для повторных и долгосрочных наблюдений, на обеих стенках, в местах пересечения лазерным лучом горизонтальной плоскости, наносится крест с указанием номера сечения. 
Таблица 3

Результаты съемки сечения

Горизонт

Блок

Выработка

База прибора 150 (вода)

\begin{tabular}{|c|c|c|c|c|c|}
\hline $\begin{array}{c}\alpha, \\
\text { град }\end{array}$ & $L, \mathrm{~cm}$ & Примечание & $\begin{array}{c}\alpha, \\
\text { град }\end{array}$ & $\begin{array}{l}L, \\
\mathrm{~cm}\end{array}$ & $\begin{array}{c}\text { Примечан } \\
\text { ие }\end{array}$ \\
\hline 0 & 320 & Запад & 180 & $\begin{array}{c}15 \\
0\end{array}$ & Восток \\
\hline 10 & 340 & & 190 & & \\
\hline 20 & 360 & & 200 & & \\
\hline $30 / 36$ & $\begin{array}{c}395 / 42 \\
0\end{array}$ & $\begin{array}{c}\text { / Начало динамического } \\
\text { заколообразования }\end{array}$ & 210 & & \\
\hline 40 & 450 & & 220 & $\begin{array}{c}19 \\
4\end{array}$ & $\begin{array}{c}\text { Подошва } \\
\text { (навал) }\end{array}$ \\
\hline $\begin{array}{l}50 / 58 \\
\end{array}$ & $\begin{array}{c}512 / 54 \\
2\end{array}$ & / Максимум & 230 & & \\
\hline 60 & 535 & & 240 & & \\
\hline 70 & 440 & & 250 & & \\
\hline 80 & 385 & & 260 & & \\
\hline 90 & 356 & $\begin{array}{c}\text { Окончание динамического } \\
\text { заколообразования }\end{array}$ & 270 & $\begin{array}{c}15 \\
0\end{array}$ & $\begin{array}{c}\text { База } \\
\text { (порода) }\end{array}$ \\
\hline 100 & 325 & & 280 & & \\
\hline 110 & 307 & & 290 & & \\
\hline 120 & 270 & & 300 & & \\
\hline 130 & 225 & & 310 & & \\
\hline 140 & 185 & & 320 & & \\
\hline 150 & 170 & & 330 & & \\
\hline 160 & 158 & & 340 & $\begin{array}{c}25 \\
0 \\
\end{array}$ & $\begin{array}{c}\text { Подошва } \\
\text { (навал) }\end{array}$ \\
\hline 170 & 153 & & 350 & & \\
\hline
\end{tabular}

Дата

Исполнитель

Примечание. $\alpha-$ угол наклона луча лазерной рулетки; $L-$ измеренное расстояние до точки замера. 


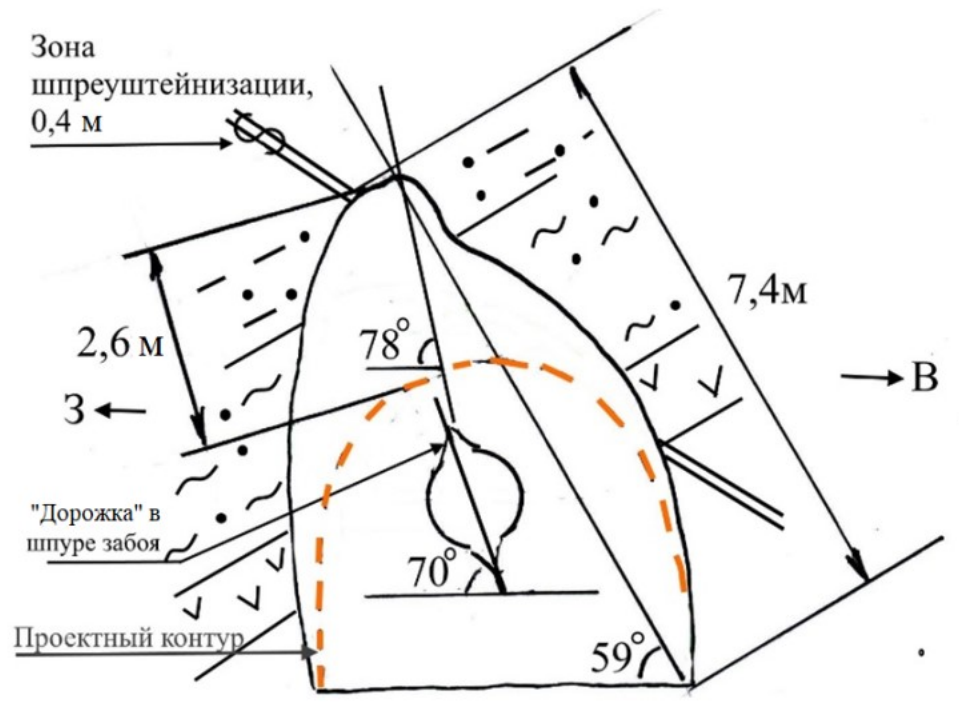

Рис. 25. Эскиз сечения

\section{5. Камеральная обработка}

Камеральную обработку полевых наблюдений рекомендуется производить сразу после выхода из рудника (шахты) или на следующий день. Практика показывает, что чем продолжительнее перерыв между полевыми и камеральными работами, тем больше неточностей и ошибок может быть допущено при их обработке.

Камеральная обработка результатов визуального обследования заключается в следующем.

1. Выполняется редактирование и подписание фотоснимков.

2. Отстраиваются сечения (рис. 24).

3. Подготавливаются и пополняются чистовые экземпляры выкопировок с маркшейдерских планов (планшетов) масштаба $1: 1000$ (рис. 20), на которые наносятся (поднимаются):

- название предприятия (рудника, шахты или месторождения), номер блока, высотная отметка и дата проведения работ;

- рудничная сетка координат;

- проходка выработок и общая конфигурация отбойки на момент проведения наблюдений; 
- геологическая информация: контакты пород с контрастными физикомеханическим свойствами (руда - порода); структурные неоднородности с элементами залегания;

- положение бровки обрушения с указанием высотных отметок (при системах с обрушением) [10];

- граница отбойки по вышележащему горизонту;

- результаты полевых наблюдений, точки фотосъемки и места съемок сечений.

Вариант заполнения фрагмента чистового плана приведен на рис. 20.

4. Заполняется Журнал визуальных наблюдений за выработками с внешними признаками удароопасности (Указания... [5, 6]).

3. Составляется акт визуальных обследований (приложение 4), в котором перечисляются выработки, где обнаружены внешние признаки удароопасности, с указанием форм проявления, категорий состояния, координат и протяженности участка.

Акт подготавливается после завершения осмотра территории каждого горно-технологического участка. Он может использоваться при подготовке материалов к заседаниям комиссии по горным ударам, при составлении годовых и квартальных отчетов, а также при подготовке аналитических записок. В дополнение к акту рекомендуется результаты визуальных обследований отображать в виде таблицы (приложение 4). 


\section{ЗАКЛЮЧЕНИЕ}

На предприятиях визуальное обследование чаще всего применяется в качестве экспресс-метода локального прогноза оценки состояния приконтурной части выработок в текущем режиме, в процессе которого определяется характер разрушений, устанавливается категория состояния, обосновываются необходимость и место заложения замерных станций инструментального контроля, подготавливаются предложения для выбора противоударных мероприятий. В решении таких задач визуальное наблюдение заняло ведущее положение на ряде предприятий среди прочих методов локального прогноза удароопасности.

При регулярном и планомерном выполнении визуальных наблюдений, охвате всего месторождения получаемая информация обладает достаточно высокой информативностью и надежностью, что позволяет применять визуальное обследование в качестве экспресс-метода локального прогноза, а также эффективно использовать его в качестве регионального метода текущего, перспективного и ретроспективного прогнозов. Результаты визуального обследования в совокупности с данными инструментальных методов, анализом иной информации о состоянии массива (геологической, сейсмологической и пр.) являются основой геодинамического районирования, выделения активных разломных структур и блоков, оценки направления и уровня максимальной компоненты главных напряжений на разных участках месторождения. Полученные данные необходимы для обоснования организационных и технических мероприятий по порядку ведения всего комплекса горных работ: вскрытию, подготовке, нарезке, отбойке, проходке отдельных выработок и закладке капитальных сооружений. Они также являются составной частью материалов для подготовки экспертной оценки, в которой определяются причины проявлений повышенного горного давления и прогноз состояния выработок при изменении горнотехнической ситуации. Оценка выработок по категории состояния является основой для выбора вида крепления.

Основные положения и принципы проведения визуального наблюдения, изложенные в работе, применимы при определенной корректировке и на других горнорудных предприятиях, разрабатывающих склонные и опасные по горным ударам месторождения, где рудное тело и вмещающие породы способны к хрупкому разрушению.

Субъективность оценки состояния массива визуальным методом не исключена, но опытный специалист СППГУ сводит ошибки до допустимого минимума. Как показала практика, время, необходимое для подготовки квалифицированного специалиста, составляет не менее двух лет. Так как преимущественное влияние на состояние приконтурной части массива оказывает его петрографическое и структурное строение, подготовка лиц, имеющих горно-геологическое и геомеханическое образование, занимает меньше времени и дает более качественный результат. 


\section{ЛИТЕРАТУРА}

1. Геомеханика: учеб. пособие / Э. В. Каспарьян и др. М.: Высш. шк., 2006. $503 \mathrm{c}$.

2. Макаров А. Б. Практическая геомеханика: пособие для горных инженеров. М., 2006. $391 \mathrm{c}$.

3. Методика регионального прогноза удароопасности и состояния массива пород и выбора технических решений по обеспечению безопасности и эффективности горных работ / А. А. Козырев и др. // Инновационный потенциал Кольской науки / под ред. В. Калинникова. Апатиты, 2005. С. $52-56$.

4. Марков Г.А., Савченко С.Н. Напряженное состояние пород и горное давление в структурах гористого рельефа. «Наука», 1984, 140 с.

5. Указания по безопасному ведению горных работ на месторождениях, склонных и опасных по горным ударам (месторождение Олений ручей) / А. А. Козырев и др. Апатиты, 2015. 101 с.

6. Указания по безопасному ведению горных работ на месторождениях, склонных и опасных по горным ударам (Хибинские апатит-нефелиновые месторождения) / А. А. Козырев и др. Апатиты, 2016. 112 с.

7. Федеральные нормы и правила в области промышленной безопасности «Положение по безопасному ведению горных работ на месторождениях, склонных и опасных по горным ударам»: утв. Приказом Ростехнадзора от 2 декабря 2013 г. № 576 // HПА: нормативно-правовые акты: сайт. URL: https://bazanpa.ru/rostekhnadzor-prikaz-n576-ot02122013-h2274309/ (дата обращения: 23.11.2020).

8. Инструкция по креплению горных выработок на месторождении апатитнефелиновых руд Олений ручей / А. А. Козырев и др. Апатиты, 2015. 72 с.

9. Федеральные нормы и правила в области промышленной безопасности «Правила безопасности при ведении горных работ и переработке твердых полезных ископаемых»: утв. Приказом Ростехнадзора от 11 декабря 2013 г. № 599 // Консорциум Кодекс: сайт. URL: http://docs.cntd.ru/document/ 499066482 (дата обращения: 23.11.2020).

10. Указания по управлению обрушением покрывающих пород, охране сооружений и природных объектов от вредного влияния подземных разработок на рудниках открытого акционерного общества «Апатит» / А. А. Козырев и др.; Горный институт КНЦ РАН, ОАО «Апатит». Апатиты, 2002. $52 \mathrm{c}$. 
ПРИЛОЖЕНИЯ 


\section{Приложение 1}

\section{ОСНОВНЫЕ ПОНЯТИЯ И ОПРЕДЕЛЕНИЯ}

Внешние признаки удароопасности - нарушение сплошности массива в приконтурной части выработок под воздействием повышенного горного давления (к ним относятся: шелушение, динамическое заколообразование и стреляние)

Геодинамически активные зоны - зоны разломов, по которым наиболее вероятно возникновение сейсмических явлений: толчков, горных ударов, горно-тектонических ударов и техногенных землетрясений

Горный удар - мгновенное хрупкое разрушение предельно-напряженного целика или краевой части массива, проявляющееся в виде выброса руды (породы) в подземные выработки с нарушением крепи, смещением машин, механизмов, оборудования и вызывающее нарушение технологического процесса, сопровождается резким звуком, сильным сотрясением горного массива, образованием пыли и воздушной волны

Динамическое заколообразование - образование и отделение заколов вслед за их оборкой в течение длительного времени, сопровождаемое треском и звуками, напоминающими выстрел. Это явление чаще всего происходит по ненарушенному массиву и не связано напрямую с трещиноватостью и слоистостью, образующиеся пластины повторяют по форме контур выработки

«Дорожка» - разрушение противоположных стенок скважины под влиянием действующих в массиве напряжений, является аналогом проявления внешних признаков удароопасности в выработке с учетом масштабного фактора

Заколообразование нединамическое - см. заколы геологического и технологического происхождения

Заколы геологического происхождения - заколы, отделение которых от массива происходит по трещинам, напластованию или по контакту пород с контрастными прочностными свойствами

Заколы динамического происхождения - см. динамическое заколообразование

Заколы технологического происхождения - заколы, отделение которых обусловлено преимущественно взрывными работами

Зона опорного давления - часть массива пород в зоне влияния границы очистного пространства, в пределах которой напряжения выше, чем в нетронутом массиве 
Зона отжима - участок приконтурной части выработки, где нарушенность внешне напоминает динамическое заколообразование, но формирование заколов обусловлено действием растягивающих напряжений или деформаций

Категория состояния выработки - характеризует уровень проявления внешних признаков удароопасности по результатам визуального наблюдения

Категория удароопасности — уровень напряженности приконтурной части массива, определяющий возможность реализации горного удара и устанавливаемый инструментальными методами

Категория удароопасности «Не опасно» - соответствует неудароопасному состоянию массива и приконтурной части выработки

Категория удароопасности «Опасно» - соответствует напряженному состоянию массива и приконтурной части выработки, при котором может произойти горный удар

Локальный прогноз удароопасности - определение удароопасности отдельных участков массива или приконтурной части выработки

Проявления горного давления - реализация геодинамических процессов в массиве, проявляющаяся в нарушении целостности массива или приконтурной части выработок в виде шелушения, динамического заколообразования, стреляния, толчков, горных ударов

Региональный прогноз удароопасности — выделение удароопасных зон в пределах блока, шахтного поля или месторождения

Стреляние - отскакивание с поверхности обнажения массива пластин пород различных размеров со звуком, напоминающим выстрел

Удароопасность месторождения или его части - наличие склонных к горным ударам пород и уровня напряжений в них, при котором возможно хрупкое разрушение этих пород в процессе ведения подземных горных работ

Шелушение - постепенное разрушение поверхности обнажения породы на отдельные пластинки, из-за отслоения которых места шелушения всегда выглядят «свежими» (незапылёнными)

\section{ПРИНЯТЫЕ СОКРАЩЕНИЯ}

ФНиП-2013 - Федеральные нормы и правила в области промышленной безопасности «Правила безопасности при ведении горных работ и переработке твердых полезных ископаемых: утверждены Приказом Ростехнадзора от 11 декабря 2013 г. № 599

Положение... - Положение по безопасному ведению горных работ на месторождениях, склонных и опасных по горным ударам: утверждены Приказом Ростехнадзора от 2 декабря 2013 г. № 576 
Указания... - Указания по безопасному ведению горных работ на месторождениях, склонных и опасных по горным ударам

Инструкция... - Инструкция по охране труда для всех работников руководителей и специалистов подразделений, производящих работы в горных выработках, № 50

СППГУ — служба прогноза и предупреждения горных ударов

МДК - метод дискования керна

КРС - метод контроля за разрушением контура скважин

\section{ПРИНЯТЫЕ ОБОЗНАЧЕНИЯ}

$\sigma_{\mathrm{c}}$ — предел прочности пород при одноосном сжатии

$\sigma_{\mathrm{T}}$ - тектоническая составляющая тензора напряжений

$\sigma_{\text {н }}$ - гравитационная составляющая тензора напряжений

$\sigma_{1}$ - максимальная компонента главных напряжений

$\sigma_{\text {д }}$ - действующие напряжения (проекция максимальной компоненты главных напряжений на плоскость, перпендикулярную оси рассматриваемой выработки)

\section{НА ВЫКОПИРОВКАХ С МАРКШЕЙДЕРСКИХ ПЛАНОВ РЕКОМЕНДУЕТСЯ ПРИМЕНЯТЬ СЛЕДУЮЩИЕ СОКРАЩЕНИЯ}

C-е 04/236 - замерная станция съемки сечения и ее номер / отметка горизонта 3/C 05/236 - замерная станция инструментальной оценки категории удароопасности и ее номер / отметка горизонта Ф-32 - точка фотосъемки и ее номер на карте фотоаппарата инт. з-е - интенсивное динамическое заколообразование инт. ш-е - интенсивное шелушение 3-е - динамическое заколообразование ш-е - шелушение

н. д. з. - незначительное динамическое заколообразование

н. ш. - незначительное шелушение

н. оч. 3. - незначительное очаговое динамическое заколообразование

н. оч. ш. - незначительное очаговое шелушение

м. в. св. - место выглядит свежим

м. н. в. св. - место не выглядит свежим геол. - заколообразование, вызванное преимущественно структурной неоднородностью массива 
Приложение 2

\section{КАТАЛОГ ИДЕНТИФИКАТОРОВ КАТЕГОРИИ СОСТОЯНИЯ ВЫРАБОТОК}

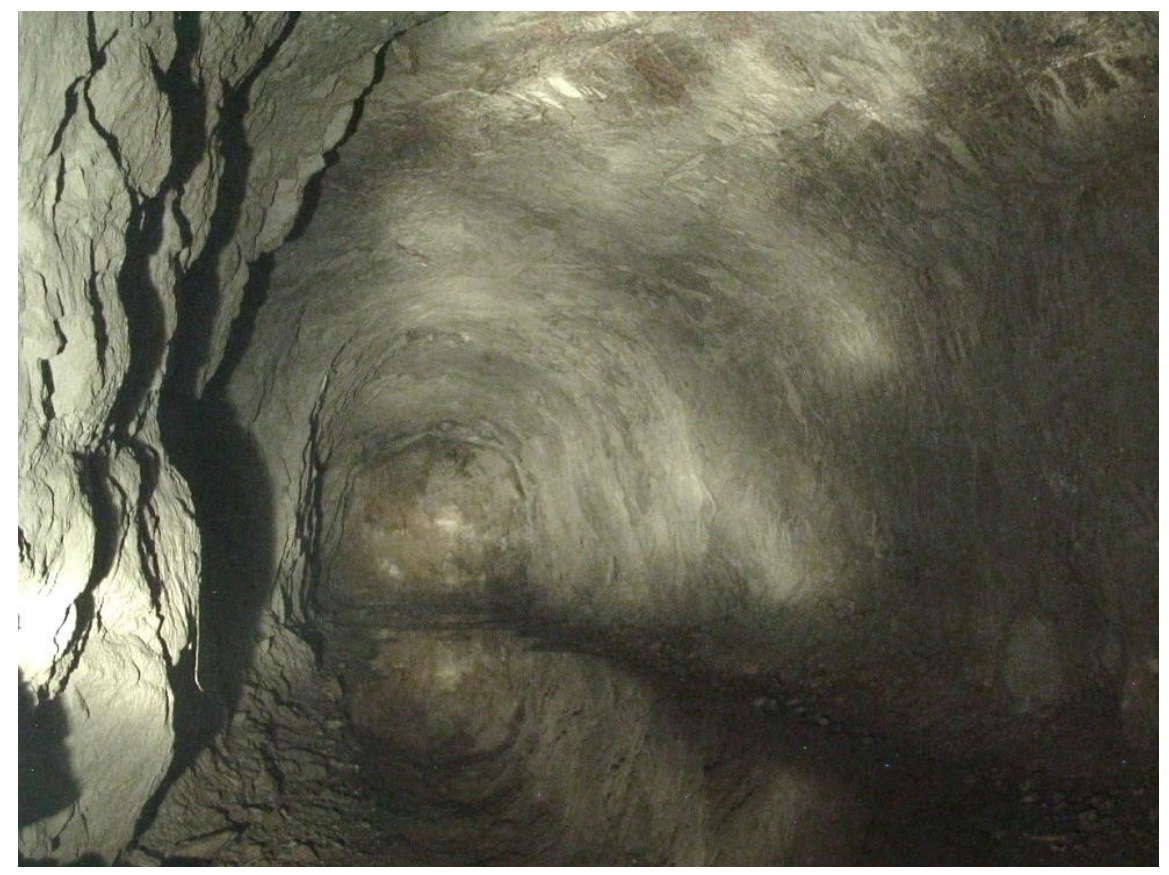

Рис. 1. Категория состояния А. Выработка сохраняет устойчивость. Расвумчоррский рудник 


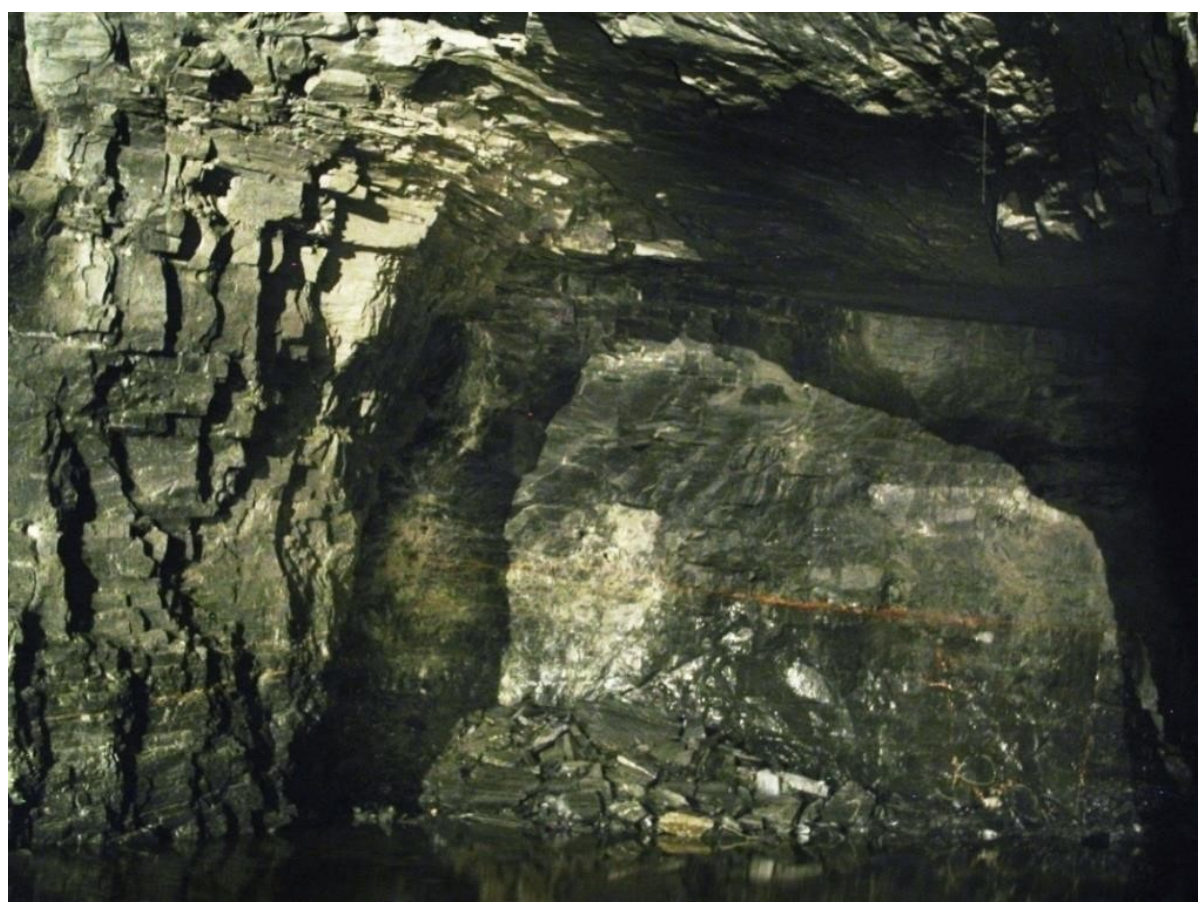

Рис. 2. Категория состояния Б-1. Наблюдаются вывалы по трещинам. Расвумчоррский рудник 


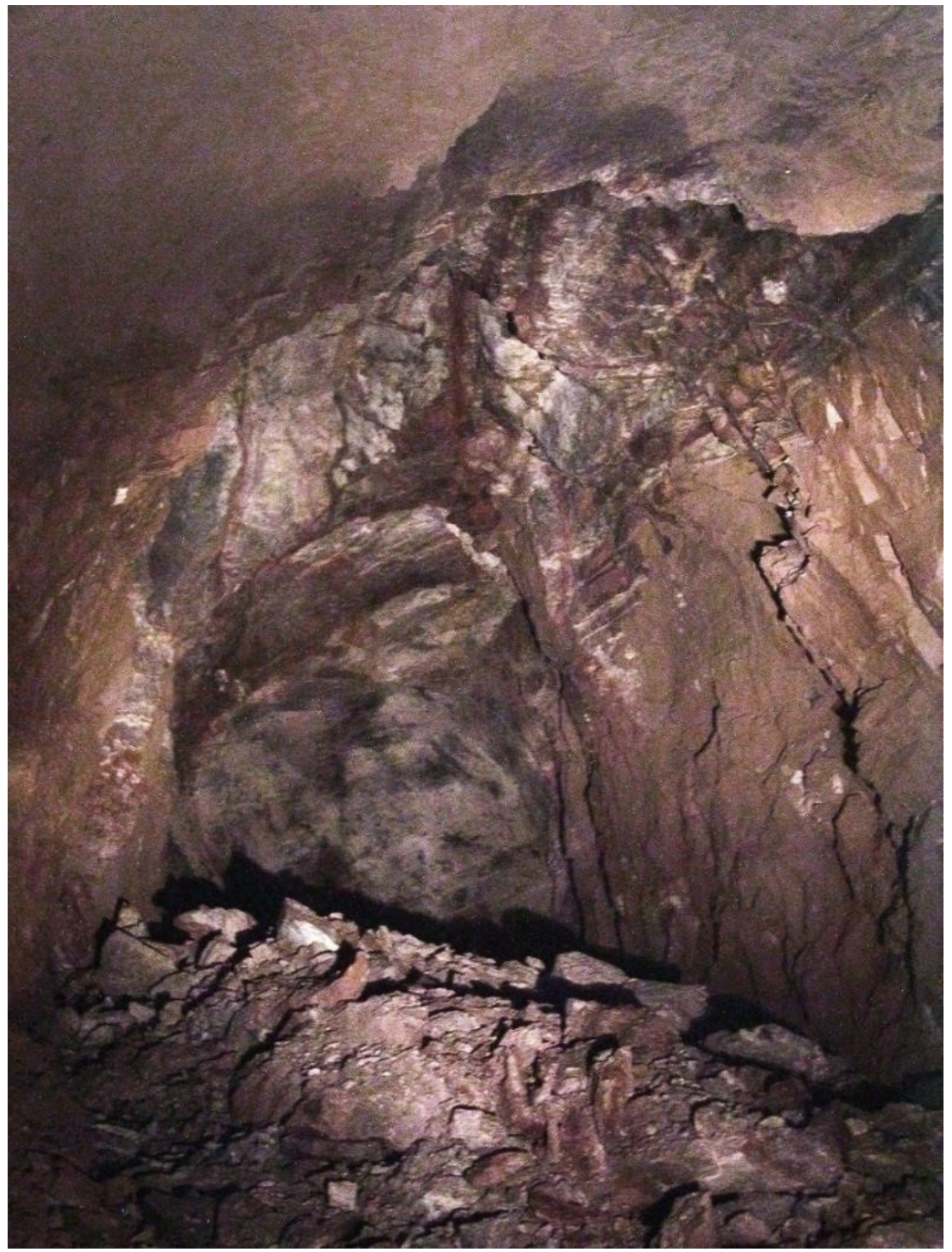

Рис. 3. Категория состояния Б-2. Вывалы по трещинам и по сплошности породы. Расвумчоррский рудник 


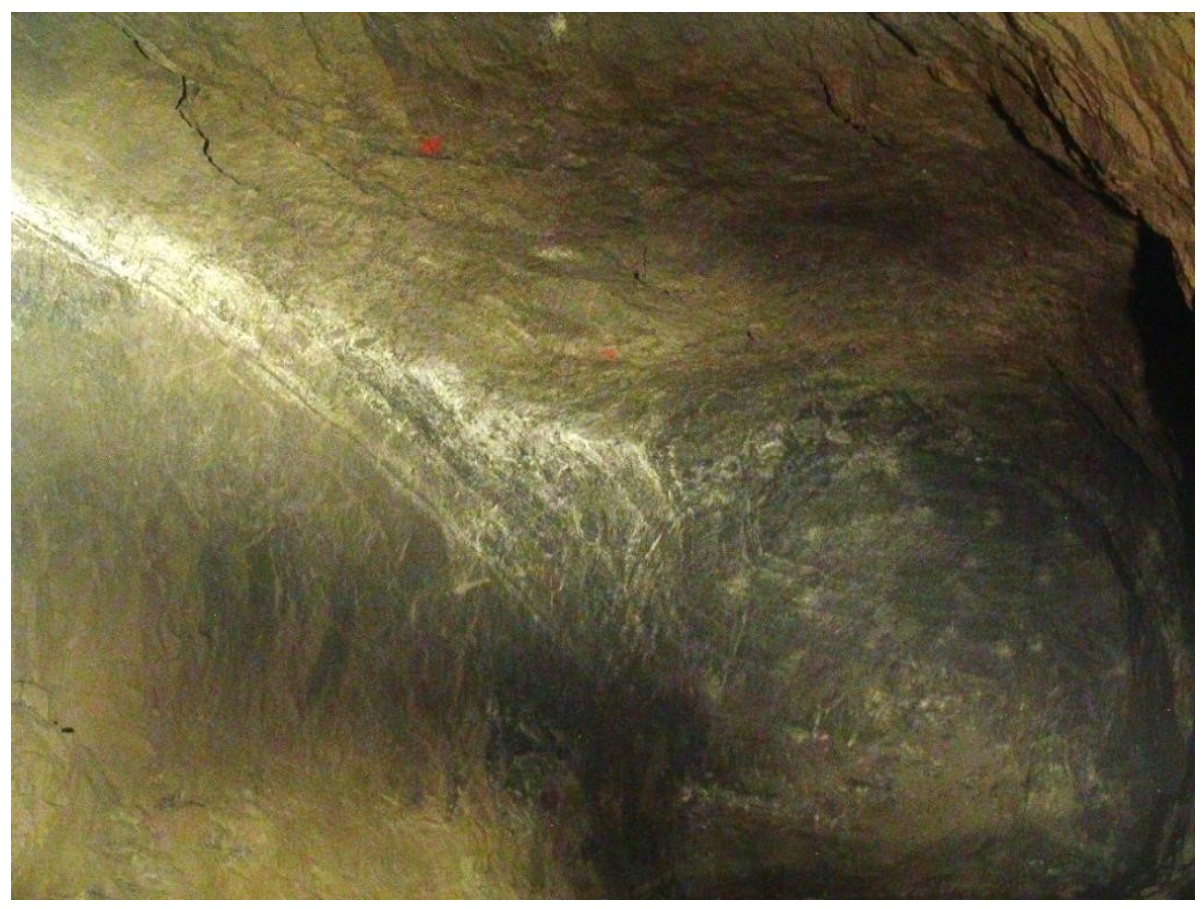

Рис. 4. Категория состояния В. Шелушение по сопряжению кровли со стенкой. Расвумчоррский рудник 


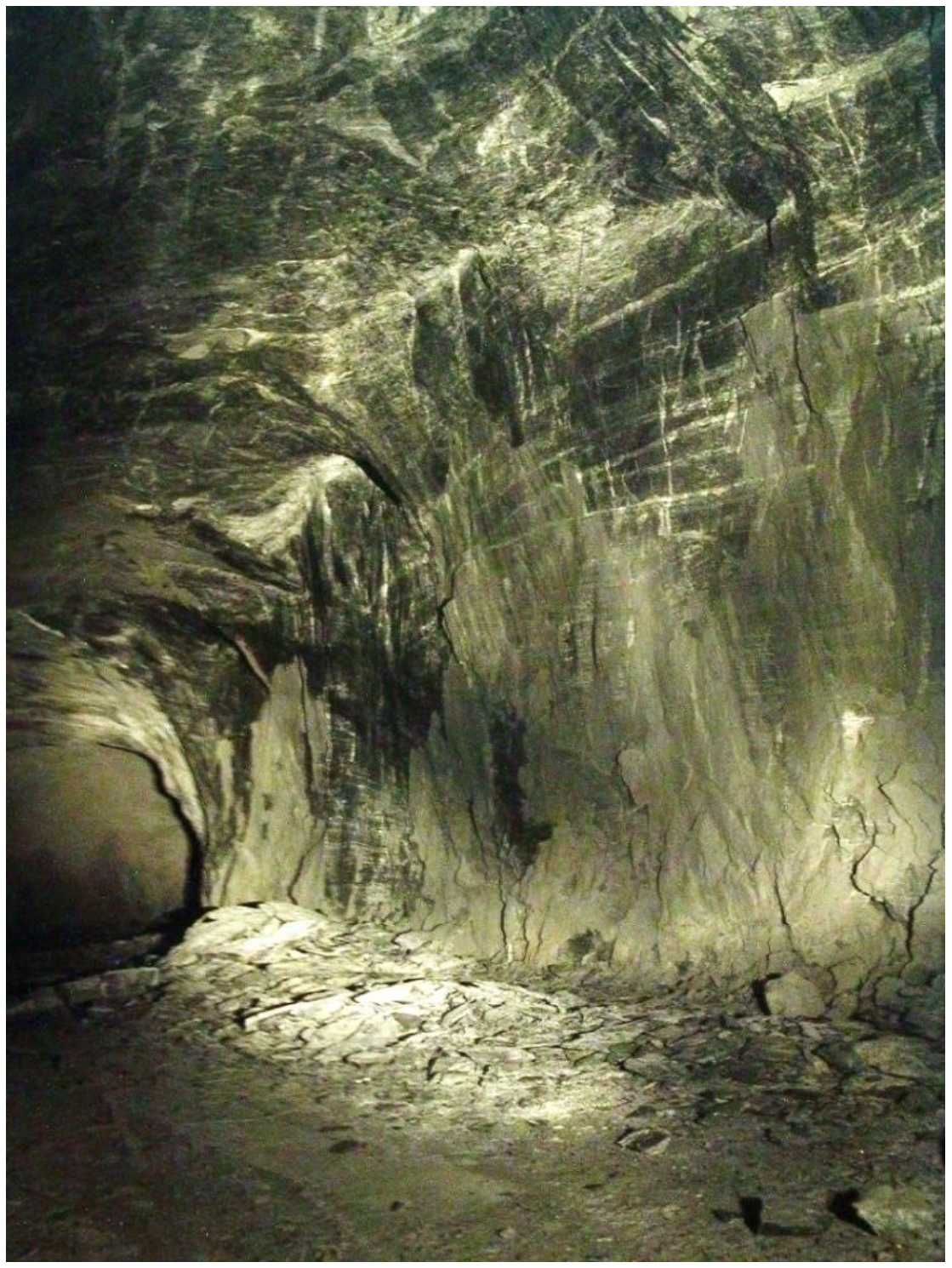

Рис. 5. Категория состояния Г. Интенсивное шелушение по сопряжению кровли со стенкой. Расвумчоррский рудник 


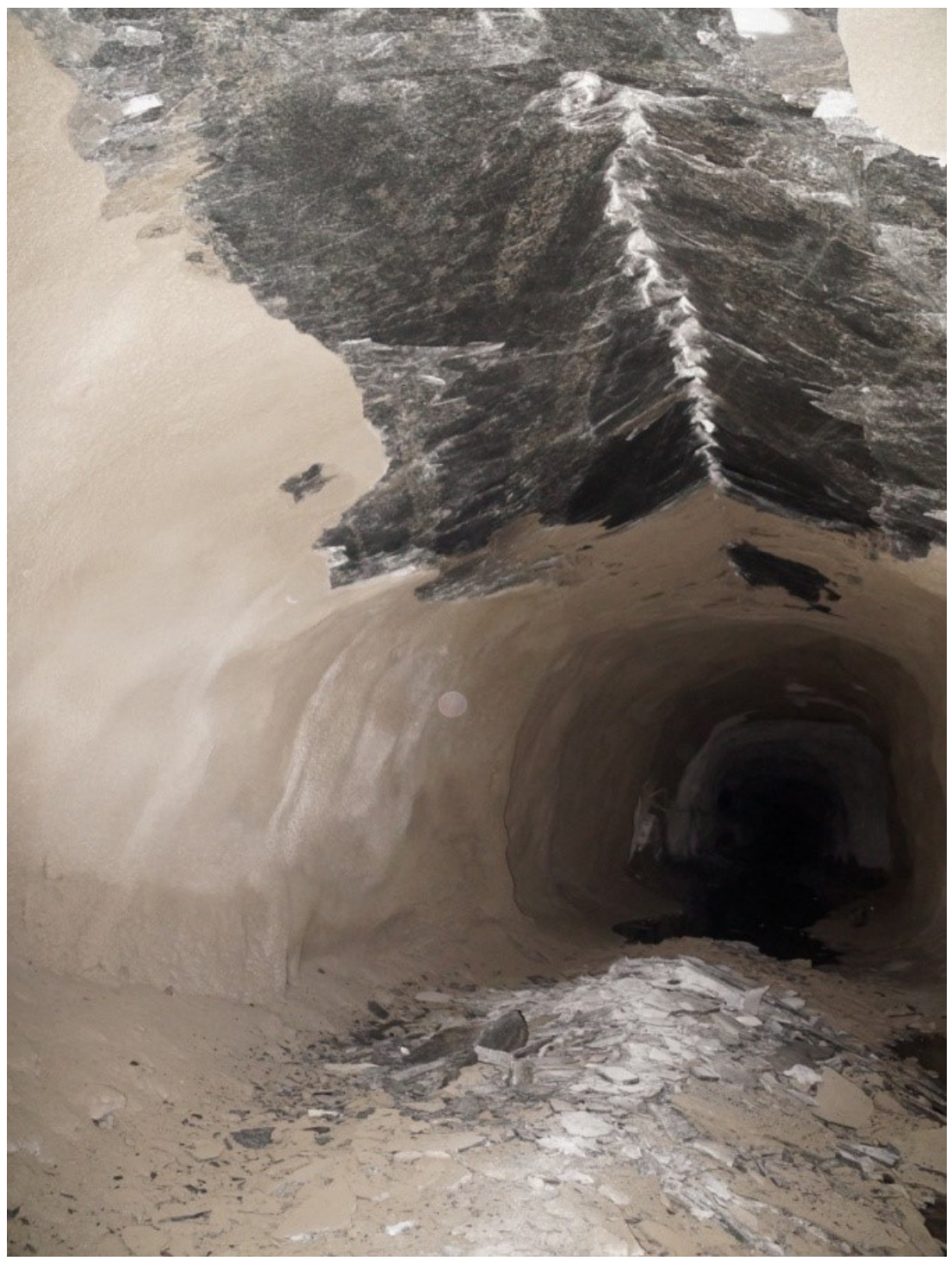

Рис. 6. Категория состояния Г. Динамическое заколообразование по кровле. Расвумчоррский рудник 


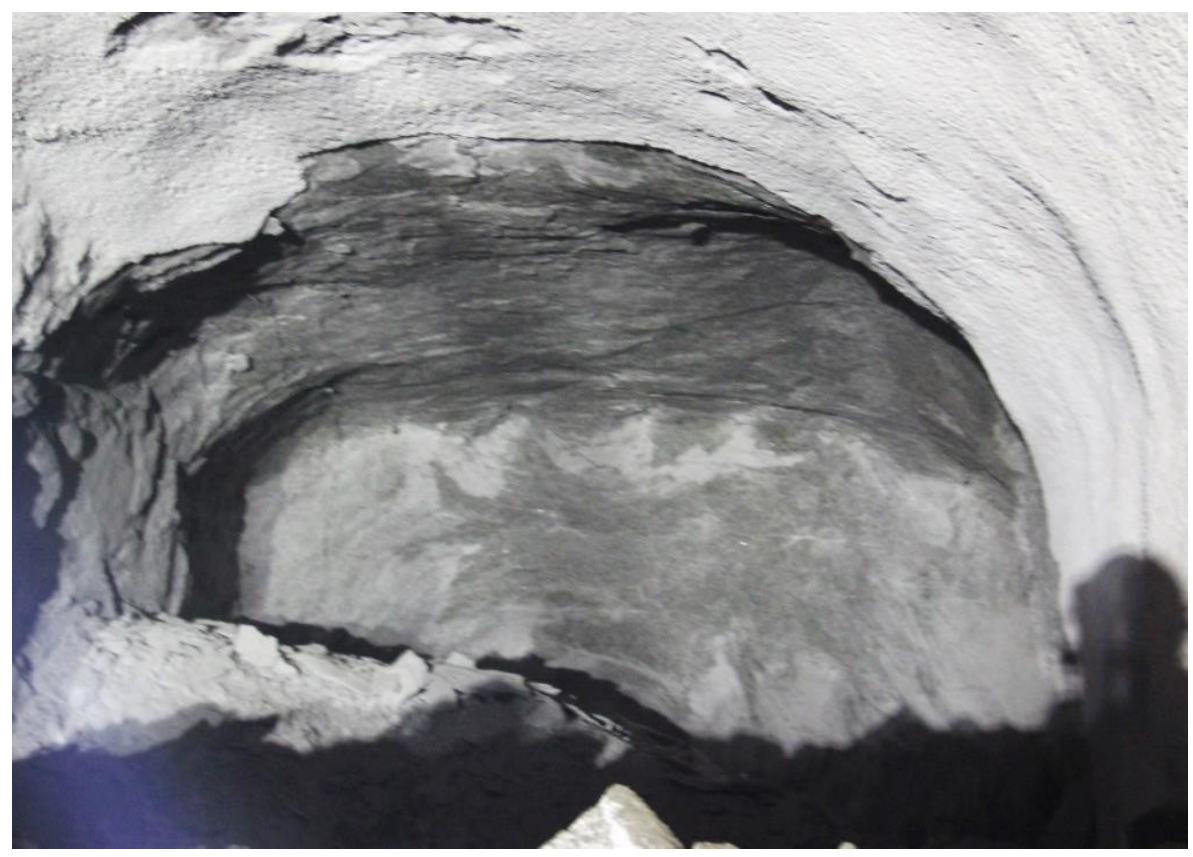

Рис. 7. Категория состояния Г. Динамическое заколообразование по кровле и ее сопряжениям со стенками при равнокомпонентном поле напряжений. Рудник «Олений ручей» 


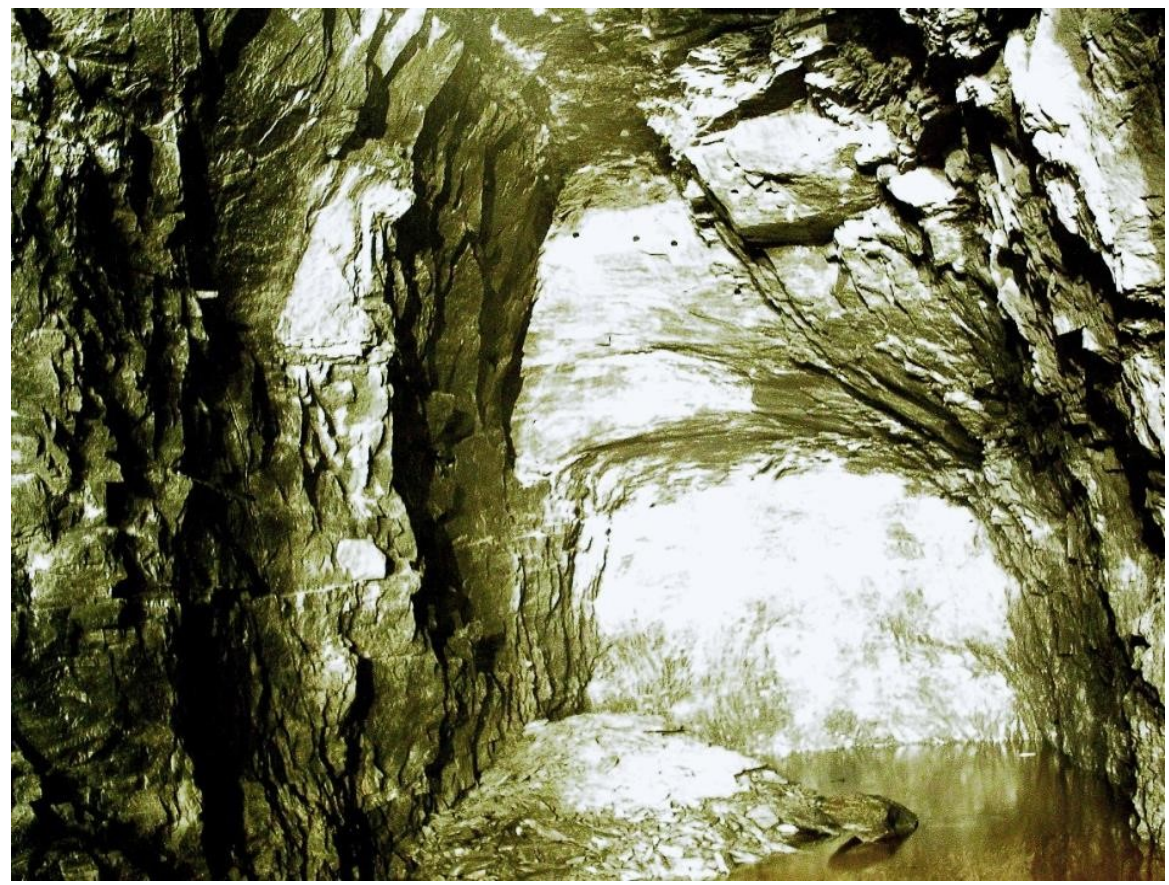

Рис. 8. Категория состояния Д. Интенсивное динамическое заколообразование по кровле. Выдавливание наблюдаемого объема породы произошло в течение суток. Расвумчоррский рудник 


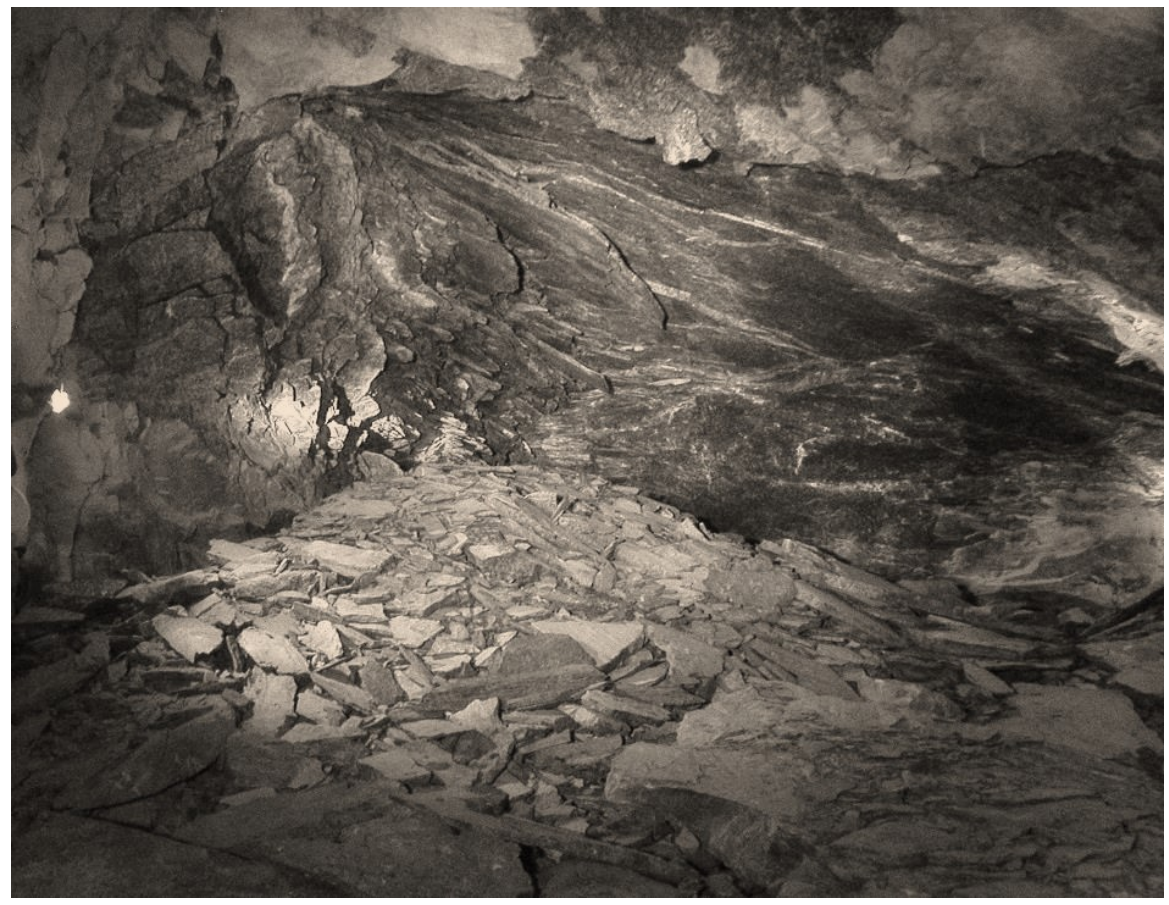

Рис. 9. Категория состояния Д. Интенсивное динамическое заколообразование по кровле, осложненное полого наклонными трещинами отдельности, вскрытыми по левой стенке. Расвумчоррский рудник 


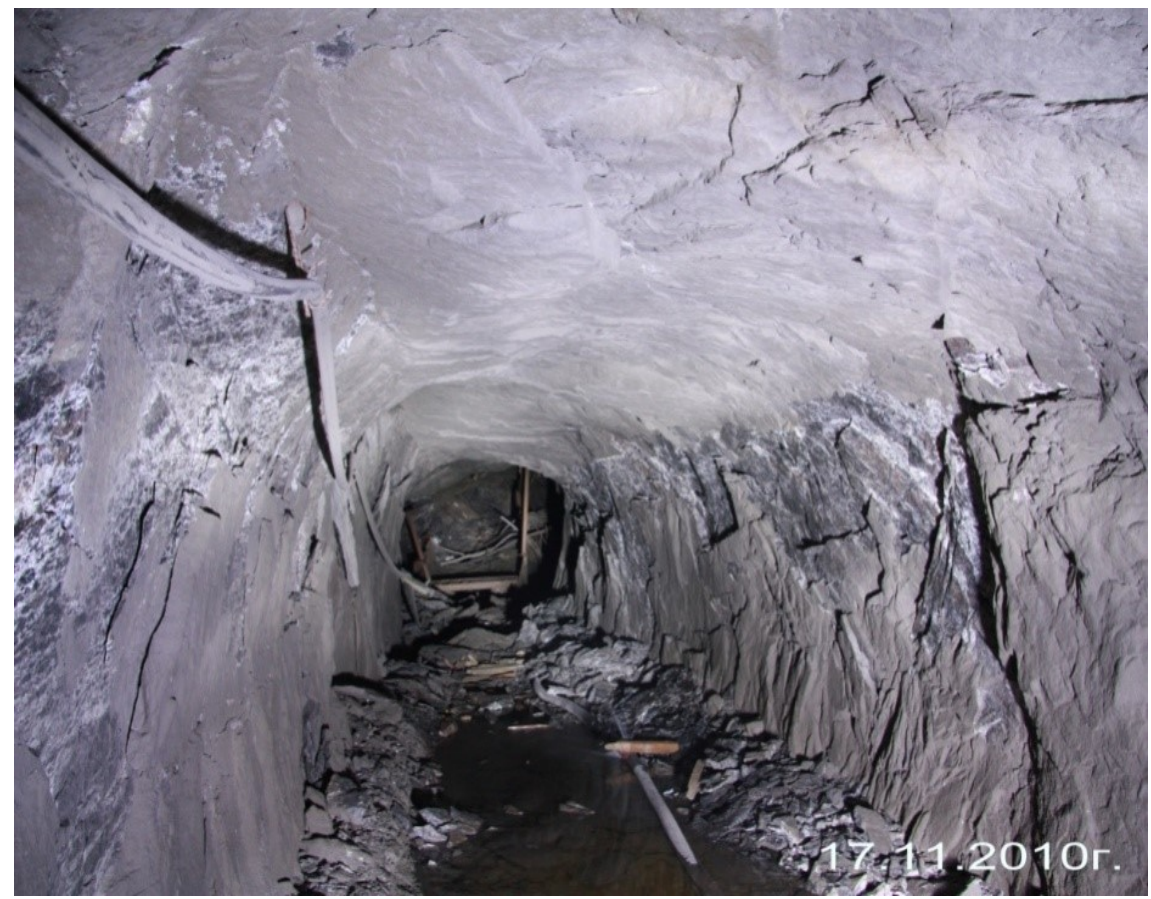

Рис. 10. Динамическое заколообразование по стенкам выработки. Расвумчоррский рудник 


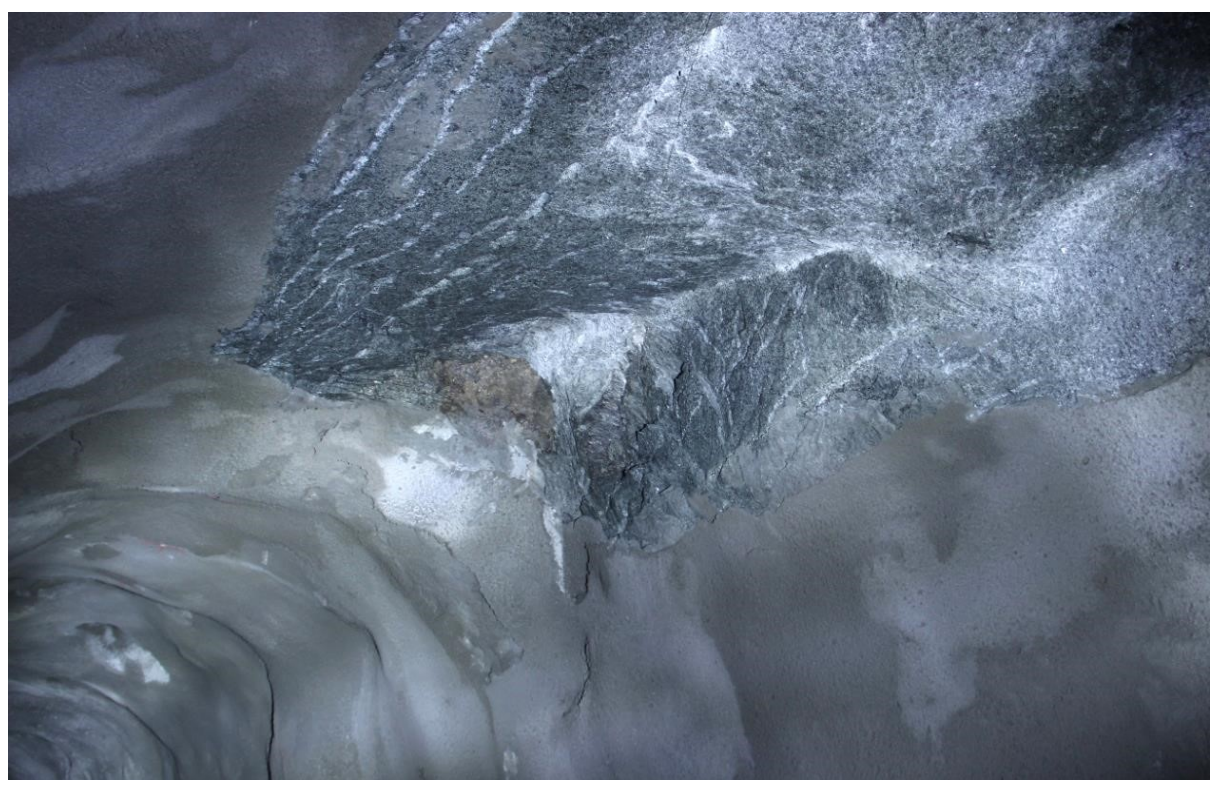

Рис. 11. Влияние отдельных трещин на перераспределение напряженного состояния массива. Рудник «Олений ручей» 


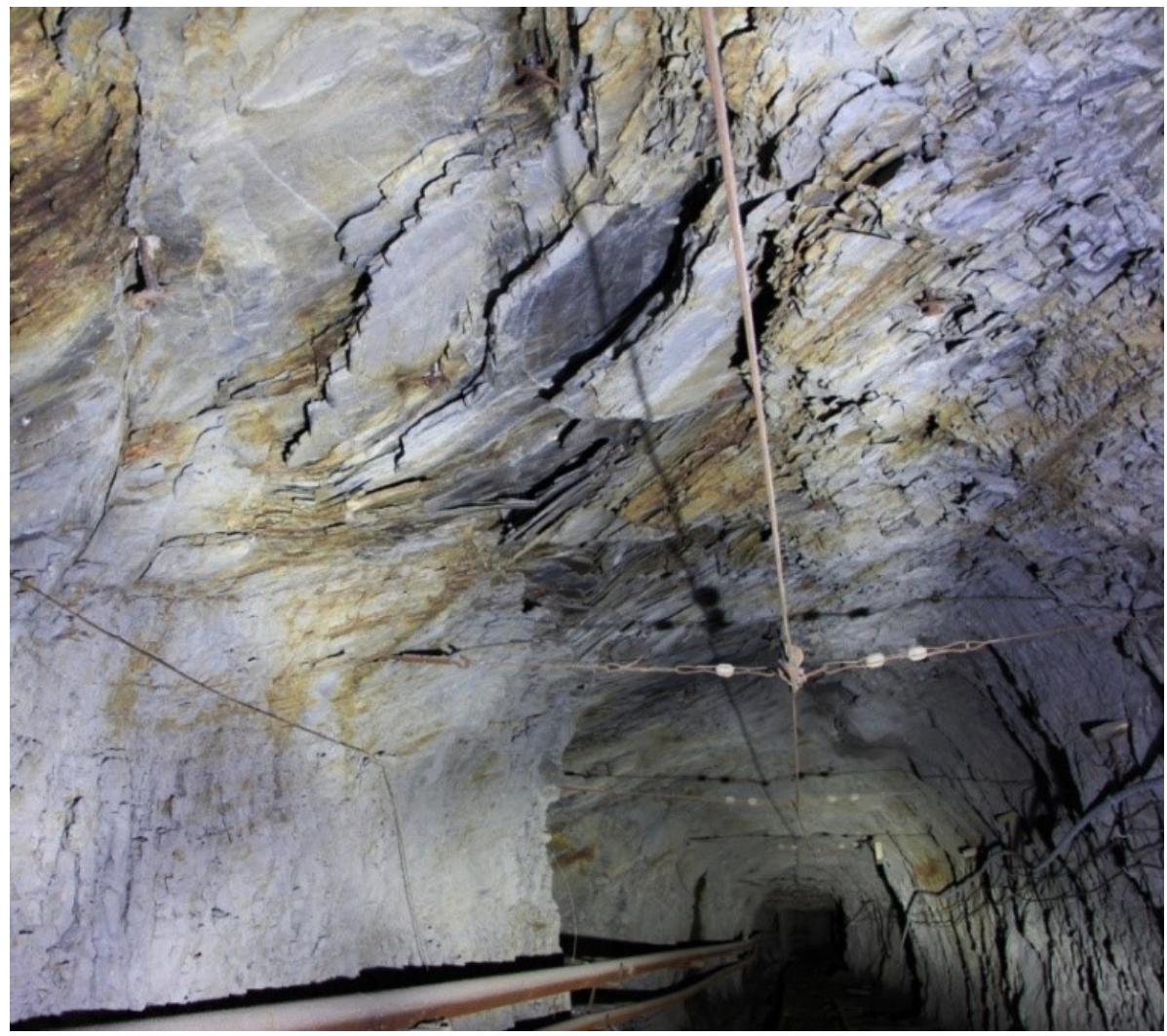

Рис. 12. Динамическое заколообразование при совпадении простирания основной системы трещин с направлением результирующего вектора напряжений. Шахта «Каула-Котсельваара» 


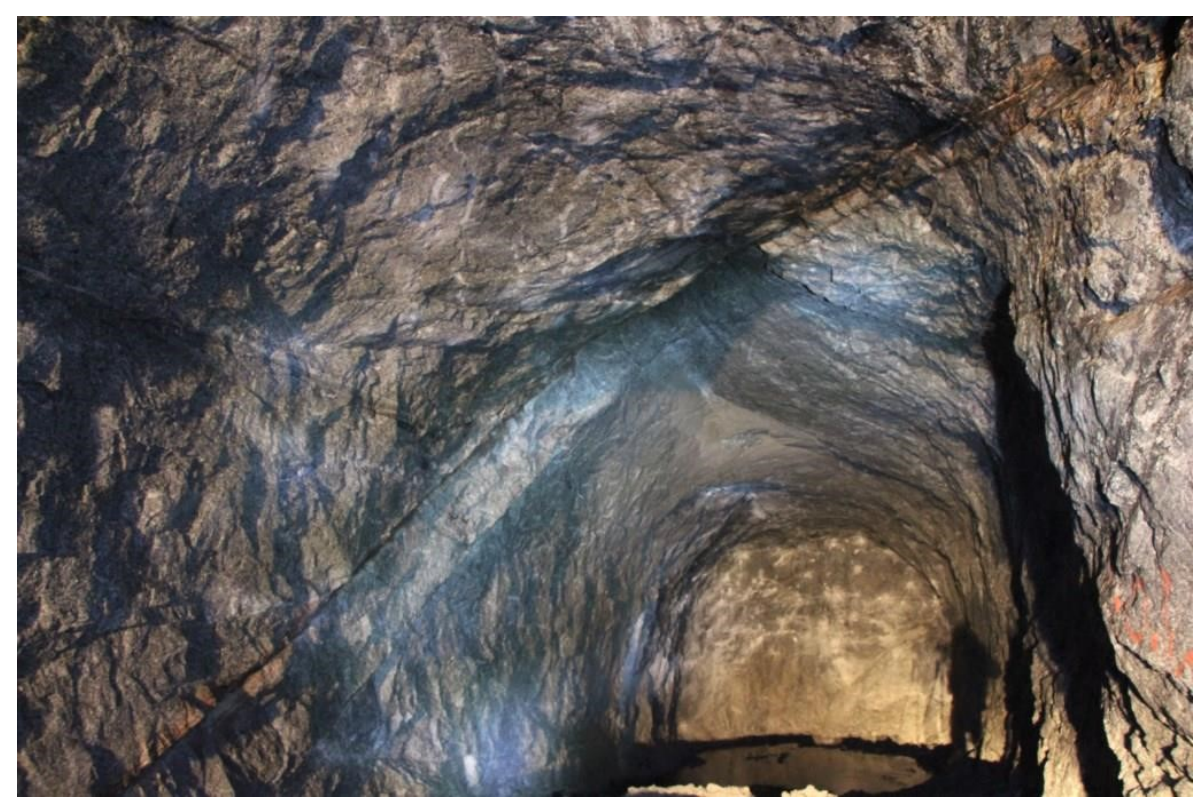

Рис. 13. Влияние разломных зон на перераспределение напряженного состояния массива. Рудник «Олений ручей» 


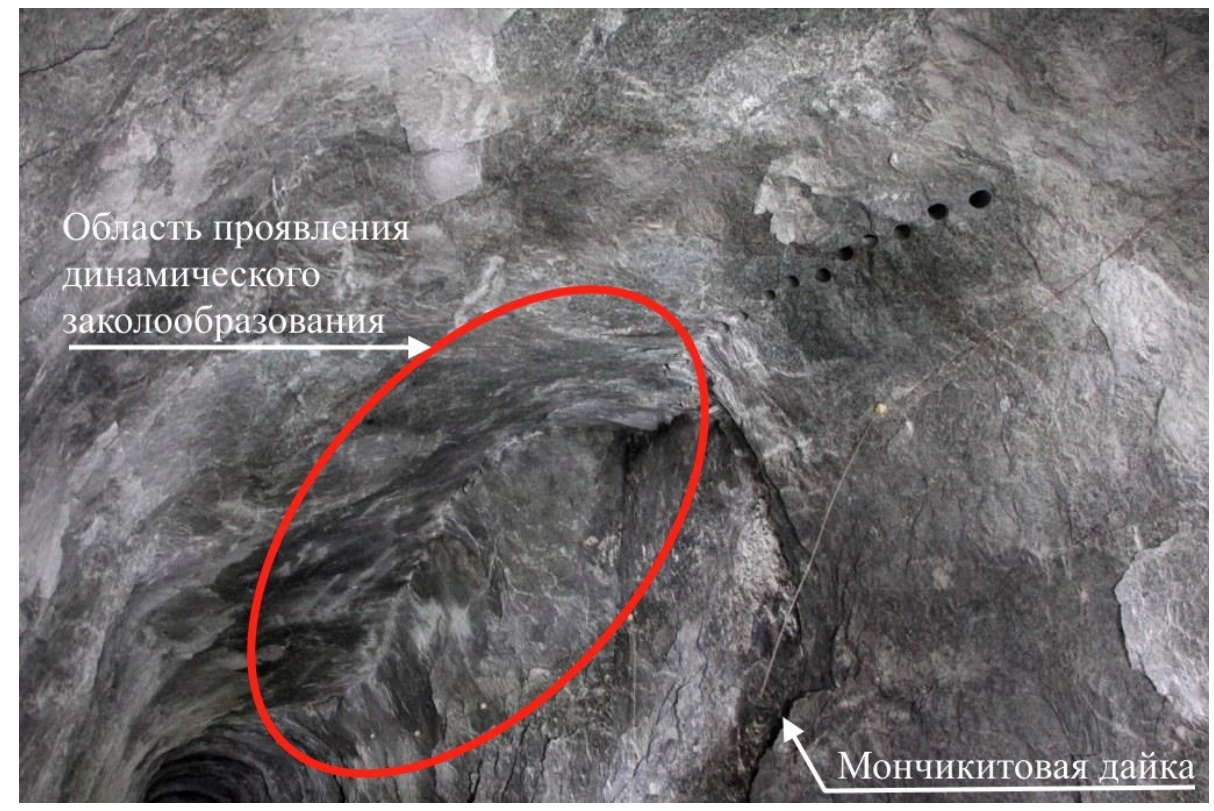

Рис. 14. Влияние мончикитовой дайки (жесткого включения) на проявление внешних признаков удароопасности. Рудник «Олений ручей» 


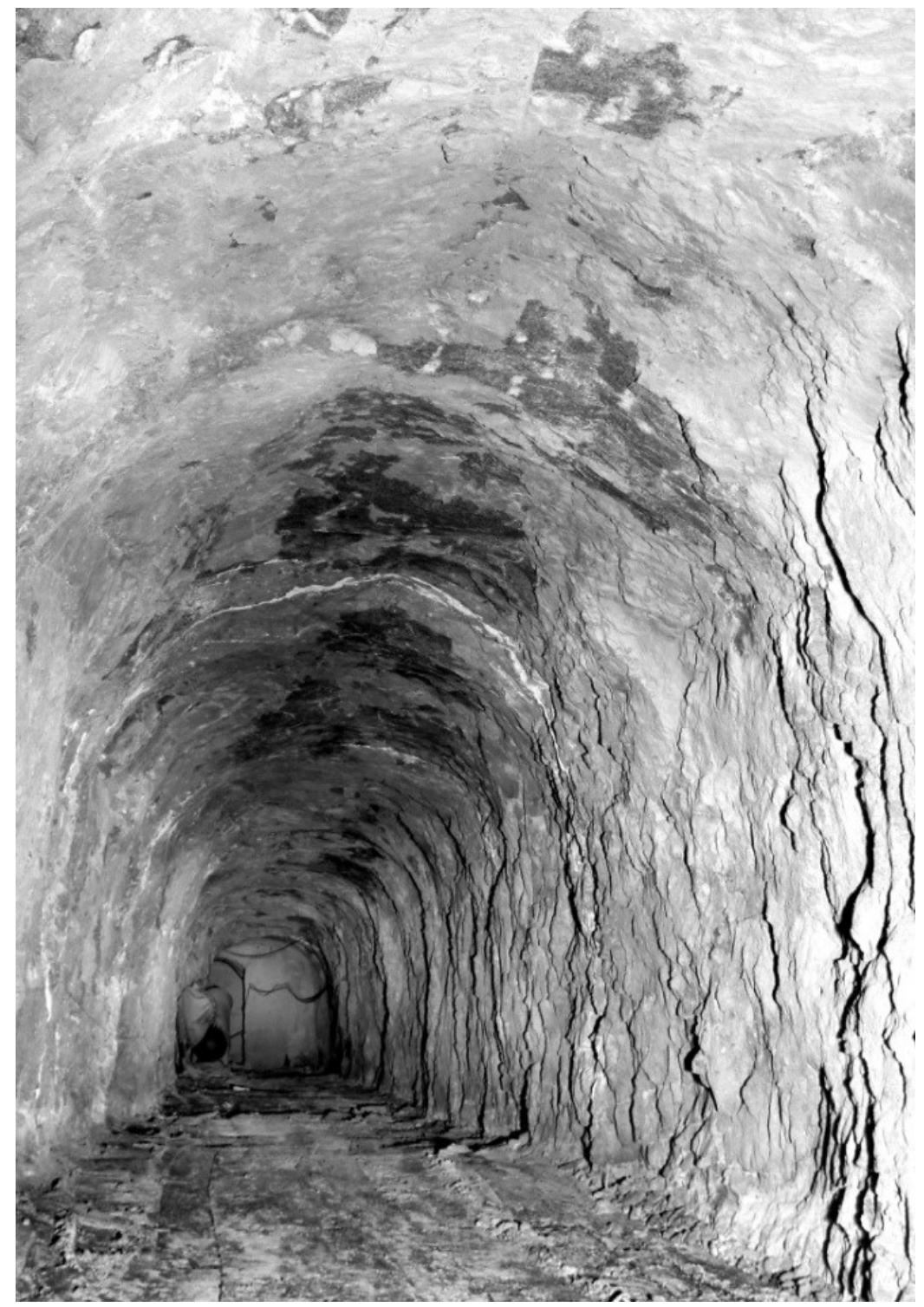

Рис. 15. Очаговое динамическое заколообразование. Рудник «Олений ручей» 


\section{УСЛОВНЫЕ ОБОЗНАЧЕНИЯ}

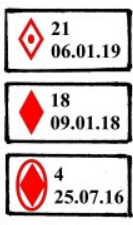

MW

$-\underset{\text { m-e }}{-}$

$\sim \underset{3-\mathrm{e}}{\sim}$

$+\neq+$

инт.ш-е

ne инт.3-е

$\longleftrightarrow \leftrightarrow$

стр-e

$\sim \sim \sim$

н.3. н.04.3.

-- - - -

Н.II. Н.оч.ш.

$\mathrm{X} \times$

$---$

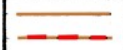

$\overline{=-}$

$\ddot{\bullet \bullet}$

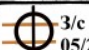

$05 / 236$

Ф-21

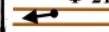

C-94/236 место микроудара

место горного удара

гипоцентр (эпицентр) толчка или

горно-тектонического удара

участки выработок, разрушенные в результате горного удара

шелушение

динамическое заколообразование

интенсивное шелушение

интенсивное динамическое заколообразование

стреляние

незначительное, очаговое заколообразование

незначительное, очаговое шелушение

нединамическое заколообразование

шелушение на кровле выработки

шелушение на сопряжении кровли со стенкой

шелушение на стенке выработки

разгрузочные строчки скважин (шпуров)

замерная станция

точка фотосъемки

точка съемки сечения 
Приложение 4

\section{АКТ ПО РЕЗУЛЬТАТАМ ПРОВЕДЕНИЯ ВИЗУАЛЬНОГО ОБСЛЕДОВАНИЯ, СВОДНЫЕ ТАБЛИЦЫ}

ОАО «АПАТИТ»

Расвумчоррский рудник

AKT

« 18 » мая 2012 г.

О результатах комиссионного обследования

горных выработок рудника с целью выявления

участков с внешними признаками удароопасности

Основание: план работы СППГУ

Комиссия в составе:

произвела комиссионное обследование горных выработок участка № 1 и установила наличие внешних признаков удароопасности в следующих выработках:

отм. $+452,0$ м:

ТШ 11 - динамическое заколообразование по кровле (проявляется от ВТО $1 / 7$ а на восток в интервале Р. $7+14 \div 7+36$, протяженность 22 м); динамическое заколообразование по сопряжению северной стенки с кровлей (проявляется от отр. орта $1 / 8$ на восток в интервале Р. $7+38 \div 7+56$, протяженность 18 м);

ВТО $1 / 7$ a - динамическое заколообразование по кровле (проявляется от

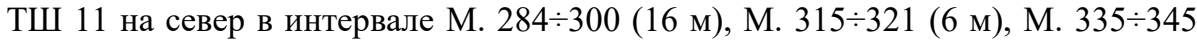
(10 м), протяженность $32 \mathrm{м})$;

отр. орт $1 / 8$ - динамическое заколообразование по кровле (проявляется от БДШ 11г на юг в интервале М. 285 $\div 385$, протяженность 100 м);

БДШ 16 - динамическое заколообразование по сопряжению южной стенки с кровлей (проявляется от ВТО $1 / 8$ на запад в интервале Р. $8+11 \div 8+25$, протяженность 14 м);

БДШ 15 - динамическое заколообразование по сопряжению южной стенки с кровлей (проявляется от ВТО $1 / 8$ на запад в интервале Р. $8+12 \div 8+20$, протяженность 8 м);

отм. $+425,0$ м: 
ВТШ - динамическое заколообразование по сопряжению южной стенки с

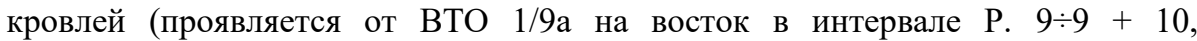
протяженность $10 \mathrm{M}$ );

ТМХШ 62 - шелушение по сопряжению южной стенки с кровлей (проявляется от ТО 9/10 на запад в интервале Р. $10+45 \div 10+55$ (10 м), Р. $11+$ $34 \div 11+54$ (20 м), протяженность 30 м).

\section{Подпись начальника СППГУ}

Подпись начальника (зам. начальника) технологического участка

\section{Сводная таблица по участку}

\begin{tabular}{|c|l|c|}
\hline \multicolumn{2}{|c|}{} & Первый участок \\
\hline \multirow{2}{*}{ Штрек } & Заколообразование & 356 \\
\cline { 2 - 3 } & Шелушение & 68 \\
\hline \multirow{2}{*}{ Орт } & Заколообразование & 256 \\
\cline { 2 - 3 } & Шелушение & 14 \\
\hline \multicolumn{2}{|l|}{ Итого: заколообразование / шелушение } & $612 / 82$ \\
\hline
\end{tabular}

Сводная таблица результатов визуального обследования по годам

\begin{tabular}{|c|l|c|c|c|c|}
\hline \multicolumn{2}{|c|}{ Первый участок } & $\begin{array}{c}\text { Июнь } \\
2015\end{array}$ & $\begin{array}{c}\text { Декабрь } \\
2015\end{array}$ & $\begin{array}{c}\text { Июнь } \\
2016\end{array}$ & $\begin{array}{c}\text { Декабрь } \\
2016\end{array}$ \\
\hline \multirow{2}{*}{ Штрек } & Заколообразование & 254 & 192 & 356 & 51 \\
\cline { 2 - 6 } & Шелушение & 36 & 0 & 68 & - \\
\hline \multirow{2}{*}{ Орт } & Заколообразование & 38 & 0 & 256 & - \\
\cline { 2 - 6 } & Шелушение & 0 & 0 & 14 & \\
\hline \multicolumn{2}{|l}{ Итого: заколообразование / } \\
\begin{tabular}{c} 
шелушение \\
\hline
\end{tabular} & $292 / 36$ & $192 / 0$ & $612 / 82$ & $51 /-$ \\
\hline
\end{tabular}

\begin{tabular}{|l|l|c|c|c|c|}
\hline \multicolumn{2}{|c|}{ Шестой участок } & $\begin{array}{c}\text { Июнь } \\
2015\end{array}$ & $\begin{array}{c}\text { Декабрь } \\
2015\end{array}$ & $\begin{array}{c}\text { Июнь } \\
2016\end{array}$ & $\begin{array}{c}\text { Декабрь } \\
2016\end{array}$ \\
\hline \multirow{2}{*}{ Штрек } & Заколообразование & 127 & 717 & 314 & 209 \\
\cline { 2 - 6 } & Шелушение & 55 & 114 & 22 & 27 \\
\hline \multirow{2}{*}{ Орт } & Заколообразование & 268 & 480 & 199 & 91 \\
\cline { 2 - 6 } & Шелушение & 8 & 55 & 8 & 0 \\
\hline $\begin{array}{l}\text { Итого: заколообразование / } \\
\text { иелушение }\end{array}$ & $395 / 63$ & $\begin{array}{c}1197 / \\
169\end{array}$ & $513 / 30$ & $300 / 27$ \\
\hline
\end{tabular}




\begin{tabular}{|l|l|c|c|c|c|}
\hline \multicolumn{2}{|c|}{ Седьмой участок } & $\begin{array}{c}\text { Июнь } \\
2015\end{array}$ & $\begin{array}{c}\text { Декабрь } \\
2015\end{array}$ & $\begin{array}{c}\text { Июнь } \\
2016\end{array}$ & $\begin{array}{c}\text { Декабрь } \\
2016\end{array}$ \\
\hline \multirow{2}{*}{ Штрекк } & Заколообразование & 765 & 1084 & 943 & 685 \\
\cline { 2 - 6 } & Шелушение & 137 & 16 & 48 & 24 \\
\hline \multirow{2}{*}{ Орт } & Заколообразование & 197 & 352 & 437 & 278 \\
\cline { 2 - 6 } & Шелушение & 14 & 0 & 8 & 18 \\
\hline $\begin{array}{l}\text { Итого: заколообразование / } \\
\text { шелушение }\end{array}$ & $962 / 151$ & $1436 / 16$ & $\begin{array}{c}1380 / \\
56\end{array}$ & $963 / 42$ \\
\hline
\end{tabular}



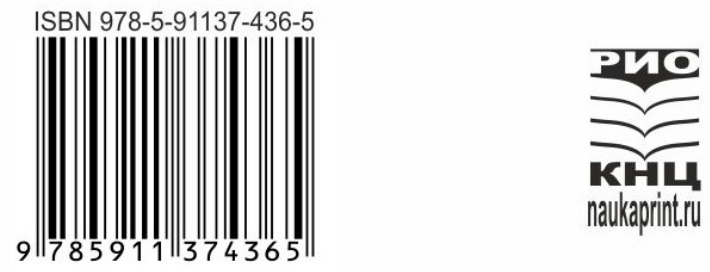

\section{咧銤}

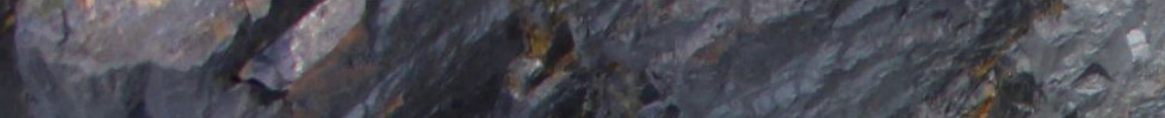

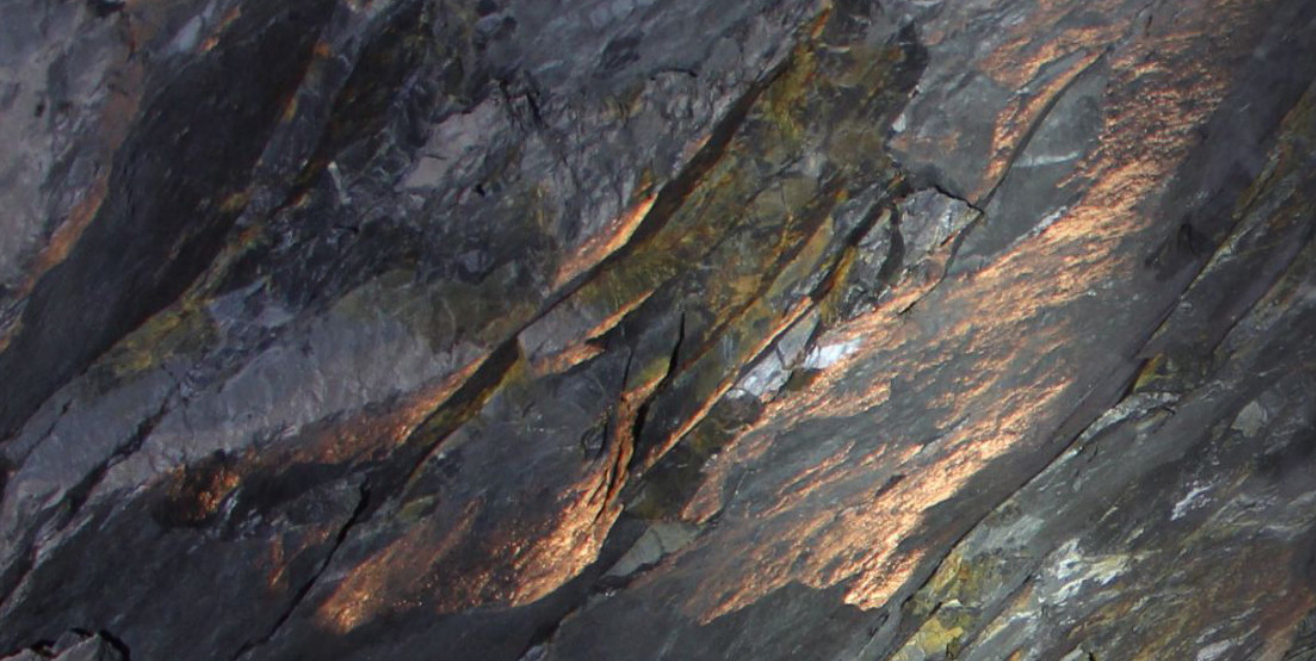

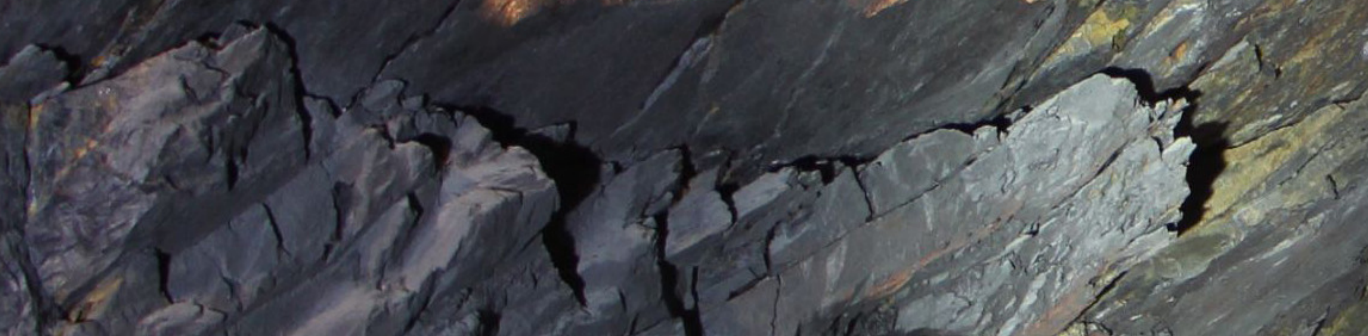

r

$x$
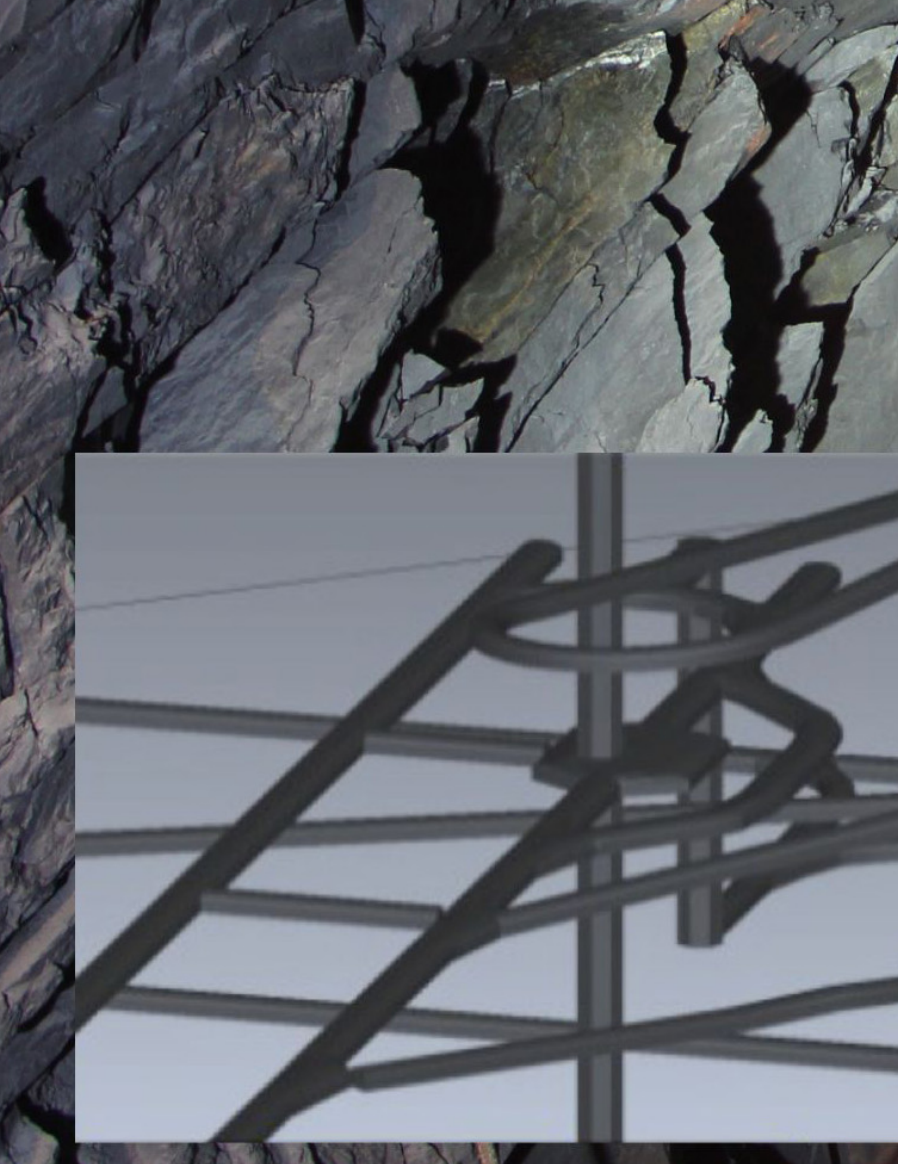